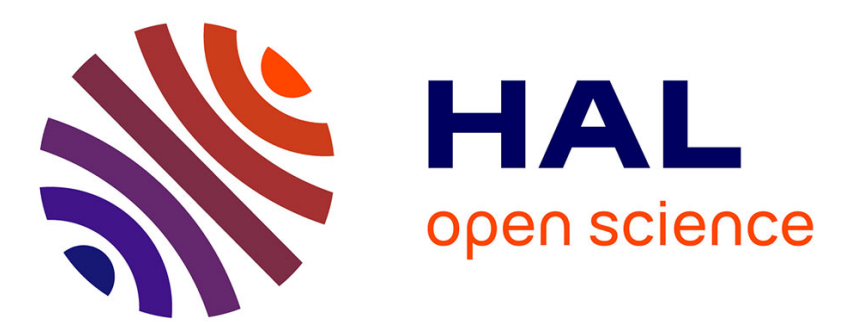

\title{
Montmorillonite colloids: II. Colloidal size dependency on radionuclide adsorption
}

Knapp Karin Norrfors, Remi Marsac, Muriel Bouby, Stephanie Heck, Susanna Wold, Johannes Lützenkirchen, Thorsten Schäfer

\section{- To cite this version:}

Knapp Karin Norrfors, Remi Marsac, Muriel Bouby, Stephanie Heck, Susanna Wold, et al.. Montmorillonite colloids: II. Colloidal size dependency on radionuclide adsorption. Applied Clay Science, 2016, 123, pp.292-303. 10.1016/j.clay.2016.01.017 . hal-01904318

\section{HAL Id: hal-01904318 \\ https://hal.science/hal-01904318}

Submitted on 24 Oct 2018

HAL is a multi-disciplinary open access archive for the deposit and dissemination of scientific research documents, whether they are published or not. The documents may come from teaching and research institutions in France or abroad, or from public or private research centers.
L'archive ouverte pluridisciplinaire HAL, est destinée au dépôt et à la diffusion de documents scientifiques de niveau recherche, publiés ou non, émanant des établissements d'enseignement et de recherche français ou étrangers, des laboratoires publics ou privés. 


\section{Montmorillonite colloids: II. Colloidal Size Dependency on Radionuclide}

\section{Adsorption}

3 Knapp Karin Norrfors ${ }^{* 1,2}$, Rémi Marsac ${ }^{1}$, Muriel Bouby ${ }^{1}$, Stephanie Heck ${ }^{1}$, Susanna Wold ${ }^{2}$, Johannes Lützenkirchen ${ }^{1}$ and 4 Thorsten Schäfer ${ }^{1}$

5 1: Karlsruhe Institute of Technology (KIT), Institute for Nuclear Waste Disposal (INE), P.O. Box 3640, D-760 21 Karlsruhe,

6 Germany

7

2: School of Chemical Science and Engineering, Applied Physical Chemistry, KTH Royal Institute of Technology,

Teknikringen 30, SE-100 44 Stockholm, Sweden

*Corresponding author. E-mail: norrfors@kth.se (K.K. Norrfors) Tel: +46 8 7909279. Fax: +46 87908772.

\section{Keywords}

Montmorillonite colloids, particle size effect, adsorption, radionuclides, nuclear waste disposal

\section{Abstract}

Bentonite is a strong radionuclide $(\mathrm{RN})$ adsorbent. As a consequence, it is proposed as one of the engineered safety barriers in many concepts of nuclear waste disposal in granite formations. Nevertheless, in contact with groundwater of low ionic strength, montmorillonite colloids may be released from the bentonite buffer and transported towards the biosphere. During the transport of colloids in bedrock fractures, size separation of clay colloids may occur, that may potentially also affect the $\mathrm{RN}$ mobility. In this work, the $\mathrm{RN}$ adsorption (Th(IV), U(VI), $\mathrm{Np}(\mathrm{V}), \mathrm{Tc}(\mathrm{VII})$ and $\mathrm{Pu}(\mathrm{IV})$ ) onto size fractionated montmorillonite colloids was studied in a synthetic, carbonated groundwater. We combined batch adsorption experiments and geochemical modelling. U(VI), $\mathrm{Np}(\mathrm{V})$ and $\mathrm{Tc}(\mathrm{VII})$ did not adsorb to the montmorillonite colloids in the synthetic groundwater. Adsorption of Th(IV) and $\mathrm{Pu}(\mathrm{IV})$ was strong but, within experimental uncertainties, not significantly affected by the mean colloidal size. In this case, average $K_{D}$ values could in principle be used in reactive transport modelling. Montmorillonite clay colloids obtained by fractionation of the raw clay material but in the presence of organic matter during the initial separation step exhibited significantly reduced affinity for Th and $\mathrm{Pu}$. 


\section{Introduction}

The deep geological repository concept for high-level nuclear waste includes several barriers (technical, geotechnical and geological) to isolate or retard the potential transport of radionuclides (RNs) towards the biosphere. Compacted bentonite is planned to be the geotechnical barrier surrounding the metal canisters (SKB, 2010). Bentonite consists mainly of montmorillonite (smectite clay) and is chosen for its favourable swelling capacities, its high cation adsorption capacities and its strong mechanical stability (Karnland et al., 2006). In case of canister failure, this geotechnical barrier will retard the RN transport towards the biosphere. However, in contact with groundwater of low ionic strength, the bentonite barrier may release stable montmorillonite colloids (Geckeis et al., 2004; Missana et al., 2003; Schäfer et al., 2012). The montmorillonite colloids can be transported through the geosphere via advective water flows (Möri et al., 2003). To be able to estimate the colloid facilitated transport of RNs, a large and complex set of parameters has to be considered.

Colloidal transport of montmorillonite through bedrock fractures depends on the ground water flow velocity (Zhang et al., 2012). At high water flow velocity, i.e. in clean bedrock fractures with a low amount of fracture filling material (FFM), a laminar water flow is expected which can separate the colloids according to their mass (for the same specific density), and thus their size. In the opposite, if the fracture contains sufficient amount of FFM, the FFM may be simplified seen as a porous medium, where larger colloids can be transported in the fastest streamlines due to size exclusion effects (Bradford et al., 2002; Sirivithayapakorn and Keller, 2003). Since size separation of montmorillonite colloids may occur in bedrock fractures, their size, morphology, stability and RN adsorption capacities are some of the important parameters for estimating colloid facilitated transport of RNs. These parameters should therefore be included in reactive transport modelling. In a recent study on montmorillonite colloidal stability performed at various ionic strengths (Norrfors et al., 2015), no dependency on the montmorillonite size could be observed. Based on this study, hydrodynamic induced size fractionation and the potential formation of different colloid size fractions will not influence their stability under the same geochemical conditions but some colloids may be able to migrate further due to e.g. steric stabilisation effects by natural occurring dissolved organic matter as fulvic acid (FA). 
It is of high importance to examine how the $\mathrm{RN}$ adsorption depends on the clay colloid size and thus, the total exposed surface area. Previous studies have demonstrated a size-dependent reactivity of hematite nano-mineral surfaces on $\mathrm{Cu}^{2+}$ adsorption (Madden et al., 2006). If the $\mathrm{RN}$ adsorption is shown to depend on the montmorillonite colloidal size, owing to their exposed lateral surface area, the amount of RNs transported through the bedrock would be over- or underestimated in the reactive transport models used today (Vahlund and Hermansson, 2006). Alternatively, if the exposed surface area does not have a large impact on the adsorption capacities, averaged adsorption capacities for montmorillonite can be used, as in the case of cation exchange, which is thought to be independent of colloidal size (Stul and Van Leemput, 1982). Tournassat et al. (Tournassat et al., 2003) suggested a model where the amount of edge sites can be calculated from the aspect ratio and the density of the clay particles by assuming a site density of silanol and aluminol edge sites per mass clay. Given the same density of all clay particles, the amount of edge sites are proportional to the aspect ratio. This model was further developed by the authors in a previous work (Norrfors et al., 2015) where montmorillonite colloids were successfully separated into fractions with varying mean colloid sizes. These colloids were used in the adsorption study presented in this work.

Accordingly, this work aims to investigate the influence of the exposed lateral surface area of montmorillonite colloids (which is related to their size) on the adsorption of trace concentrations of RNs in a synthetic groundwater (SGW) representing a glacial meltwater type (Geckeis et al., 2004; Kunze et al., 2008; Möri et al., 2003). In this work, the term clay colloids refer to aggregates, consisting of stacks of several clay mineral layers. Seven montmorillonite dispersions with different mean particle sizes, including one containing fulvic acids (FA), were used for adsorption studies with ${ }^{232} \mathrm{Th}(\mathrm{IV}),{ }^{99} \mathrm{Tc}(\mathrm{VII}),{ }^{233} \mathrm{U}(\mathrm{VI})$, ${ }^{237} \mathrm{~Np}(\mathrm{~V})$ and ${ }^{242} \mathrm{Pu}(\mathrm{IV})$ during a long (up to six months) equilibration time. The 2 sites protolysis non-electrostatic surface complexation and cation exchange (2 SPNE SC/CE) model (Bradbury and Baeyens, 2011) was used to predict the uptake of RNs. In addition, we attempted to estimate the influence of expected amounts of edge sites, calculated for each particle size, on the $\mathrm{RN}$ adsorption process.

\section{Material and Methods}

\subsection{Montmorillonite colloids and fulvic acids}


Various dispersions containing size fractionated montmorillonite colloids originating from raw Wyoming MX80 bentonite $\left(\mathrm{M}_{\mathrm{w}}=372.6 \mathrm{~g} / \mathrm{mol}\right.$ (Karnland et al., 2006)), American Colloid Co., were used in this study. Preparation and characterization of the montmorillonite dispersions are explained in detail in previous work (Norrfors et al., 2015). A summary of the preparation protocol is presented schematically in Figure 1. Details of centrifugation speeds and times are given in Table 1. In brief, the un-purified MX80 bentonite $(10 \mathrm{~g} / \mathrm{L})$ was placed into carbonated synthetic groundwater (SGW) and settled during three days. The supernatant was collected and named dispersion S0. The dispersion S0 was further separated into different size fractions by sequential or direct centrifugation. In the sequential (ultra-)centrifugation, S0 was first centrifuged to obtain supernatant S1. Thereafter, S1 was centrifuged to obtain supernatant S2 etc., resulting as well in supernatants S3 and S3.5. For comparison, S0 was also directly ultra-centrifuged (UC) to obtain the dispersion $\mathrm{S} 3.5^{\mathrm{UC}}$. It was found that the dispersions $\mathrm{S} 3.5$ and $\mathrm{S} 3.5^{\mathrm{UC}}$ exhibit the same size distribution of colloids despite the different separation protocol. All dispersions have been characterized according their size, chemical composition, mineralogical composition and colloidal concentration in a previous paper, where all details can be found (Norrfors et al., 2015). Suspension concentration was adjusted to $20 \mathrm{mg} / \mathrm{L}$ in the $\mathrm{RN}$ batch adsorption experiments.

To be able to estimate the exposed lateral surface and thus the amount of adsorption edge sites in each montmorillonite dispersions, the clay particles were assumed to be disc-shaped (Norrfors et al., 2015). Then, their mean disc diameter and height were calculated by equations developed by Jennings and Parslow (Jennings, 1993; Jennings and Parslow, 1988). For this purpose, the mean colloidal sizes of each dispersion measured by different techniques were used in the equations to obtain the mean disc sizes and heights, see Table 1 and (Norrfors et al., 2015). These diameters are mean values for the whole size distribution of colloids in the respective dispersions. S0 includes both larger and smaller sized colloids, whereas S3.5 and $\mathrm{S} 3.5^{\mathrm{UC}}$ only include smaller colloids and were therefore less polydisperse.

The amount of adsorption edge sites was calculated according to the work of White and Zelazny (White and Zelazny, 1988) and Tournassat et al. (Tournassat et al., 2003), assuming a clay density of $2.7 \mathrm{~g} / \mathrm{cm}^{3}$. The calculated mean clay particle disc diameters were used to determine their lateral area from which the amount of sites in the clay dispersions could be estimated (in mmol/kg). The estimated amounts of sites are presented in Table 1. 
Complementary, one clay suspension was prepared in presence of FA, representing natural organic matter. The fulvic acid (FA-573) has been extracted from a natural groundwater (Gohy573) of the Gorleben site, Germany (Wolf et al., 2004). A small amount of FA was weighed, dissolved in $\mathrm{NaOH}$ and diluted in a separate clay dispersion (10 g raw MX80 bentonite in $1 \mathrm{~L} \mathrm{SGW).} \mathrm{Thereafter,} \mathrm{this} \mathrm{FA-clay} \mathrm{dispersion} \mathrm{was} \mathrm{ultra-centrifuged} \mathrm{during} \mathrm{the}$ same time and at the same speed as the dispersion S3.5 ${ }^{\mathrm{UC}}$, and denoted S3.5 ${ }^{\mathrm{UC}, \mathrm{FA}}$. The final concentration of FA in the batch adsorption experiment was approximately $1.9 \mathrm{mg} / \mathrm{L}$ after dilution of the dispersion $\mathrm{S} 3.5^{\mathrm{UC}, \mathrm{FA}}$ to a concentration of $20 \mathrm{mg} / \mathrm{L}$ montmorillonite colloids.

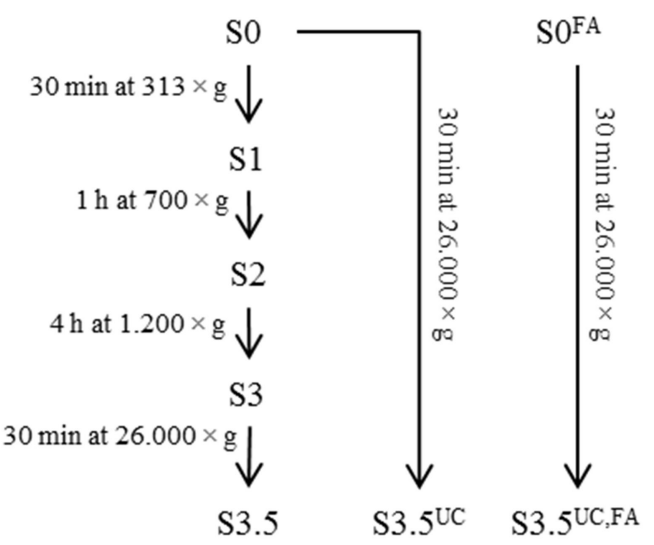

132

Figure 1: Schematic diagram of bentonite fractionation into various aggregate size fractions by sequential and direct (ultra-)centrifugation.

Table 1: Dispersions used in the batch adsorption experiments, separation protocol performed, mean diameter of the clay discs and amounts of adsorption sites determined (Norrfors et al., 2015).

\begin{tabular}{|c|c|c|c|}
\hline $\begin{array}{c}\text { Colloidal } \\
\text { dispersion }\end{array}$ & $\begin{array}{c}\text { Conditions of separation } \\
\text { (C: centrifugation; }\end{array}$ & $\begin{array}{c}\text { Mean diameter of } \\
\text { clay discs (nm) }\end{array}$ & $\begin{array}{c}\text { Amount of } \\
\text { adsorption sites } \\
\text { (mmol/kg) }\end{array}$ \\
\hline UC: ultracentrifugation) & 3 days sedimentation & 1496 & 11.2 \\
\hline S1 & C: 30 min $(\mathrm{S} 0)$ at $313 \times \mathrm{g}$ & 940 & 17.8 \\
\hline S2 & C: $1 \mathrm{~h}(\mathrm{~S} 1)$ at $700 \times \mathrm{g}$ & 500 & 33.5 \\
\hline
\end{tabular}




\begin{tabular}{|c|c|c|c|}
\hline S3 & C: $4 \mathrm{~h}(\mathrm{~S} 2)$ at $1.200 \times \mathrm{g}$ & 250 & 67.0 \\
\hline $\mathbf{S 3 . 5}$ & UC: $30 \min (\mathrm{S} 3)$ at $26.000 \times \mathrm{g}$ & 258 & 64.7 \\
\hline $\mathbf{S 3 . 5}^{\mathrm{UC}}$ & UC: $30 \min (\mathrm{S} 0)$ at $26.000 \times \mathrm{g}^{\mathrm{a}}$ & 246 & 67.9 \\
\hline $\mathbf{S 3 . 5}^{\mathrm{UC,FA}}$ & UC: $30 \min (\mathrm{S} 0)$ at $26.000 \times \mathrm{g}^{\mathrm{a}}$ & 187 & $89.5^{*}$ \\
\hline
\end{tabular}

: one step ultra-centrifugation from colloidal dispersion SO obtained after stirring and sedimentation of a MX80 dispersion at $10 \mathrm{~g} / \mathrm{L}$ in presence or absence of $11.8 \mathrm{mg} / \mathrm{L} \mathrm{FA}$. *: Amount of sites estimated from the mean colloidal size, i.e. neglecting potential site occupancy by $F A$.

\subsection{Synthetic Groundwater (SGW)}

Synthetic, carbonated groundwater (SGW) is used as background electrolyte to simulate a glacial meltwater of low ionic strength, similar to the granitic groundwater present at the Grimsel Test Site (Geckeis et al., 2004; Kunze et al., 2008; Möri et al., 2003). The SGW is prepared by mixing different salts $\left(\mathrm{NaCl}, \mathrm{CaCl}_{2}, \mathrm{MgCl}_{2}, \mathrm{NaF}, \mathrm{Na}_{2} \mathrm{SO}_{4}\right.$ and $\left.\mathrm{NaHCO}_{3}\right)$, yielding the composition presented in Table 2. The total ionic strength is $1.6 \mathrm{mM}$ and the $\mathrm{pH}$ is $8.4 \pm$ 0.1 prior to contact with montmorillonite colloids and radionuclide cocktail.

Table 2: The chemical composition of the synthetic groundwater (SGW) used as background electrolyte in all samples (Norrfors et al., 2015).

\begin{tabular}{|c|c|}
\hline Element & $\begin{array}{c}\text { Concentration } \\
(\mathbf{m M})\end{array}$ \\
\hline $\mathrm{Na}^{+}$ & 1.2 \\
\hline $\mathrm{Ca}^{2+}$ & 0.05 \\
\hline $\mathrm{F}^{-}$ & 0.1 \\
\hline $\mathrm{Cl}^{-}$ & 0.074 \\
\hline $\mathrm{SO}_{4}{ }^{2-}$ & 0.04 \\
\hline $\mathrm{HCO}_{3}^{-}$ & 1.0 \\
\hline $\mathrm{pH}$ & $8.4 \pm 0.1$ \\
\hline
\end{tabular}




\subsection{Radionuclide cocktail}

155

156

157

158

159

160

161

162

163

164

165

166

167

168

169

170

171

172

173

174

175

176

177

178

179

180

181

A radionuclide cocktail containing the elements: ${ }^{232} \mathrm{Th},{ }^{99} \mathrm{Tc},{ }^{233} \mathrm{U},{ }^{237} \mathrm{~Np}$ and ${ }^{242} \mathrm{Pu}$ was prepared in a glove box under Ar atmosphere in $0.1 \mathrm{M} \mathrm{HCl}$. The cocktail was used to spike the seven clay dispersions, diluted to $20 \mathrm{mg}$ colloids/L in the SGW. The initial (total) RN concentrations in all adsorption samples was checked by analysing the top $0.5 \mathrm{~mL}$ out of a total sample volume of $50 \mathrm{~mL}$ by ICP-MS. This yielded $\left[{ }^{232} \mathrm{Th}(\mathrm{IV})\right]=10^{-8} \mathrm{M},\left[{ }^{99} \mathrm{Tc}(\mathrm{VII})\right]=$ $5 \cdot 10^{-9} \mathrm{M},\left[{ }^{233} \mathrm{U}(\mathrm{VI})\right]=10^{-8} \mathrm{M},\left[{ }^{237} \mathrm{~Np}(\mathrm{~V})\right]=10^{-8} \mathrm{M}$ and $\left[{ }^{242} \mathrm{Pu}(\mathrm{IV})\right]=2 \cdot 10^{-9} \mathrm{M} .{ }^{242} \mathrm{Pu}$ was added as ${ }^{242} \mathrm{Pu}(\mathrm{III})$ to the radionuclide cocktail, but based on thermodynamic considerations, $\mathrm{Pu}(\mathrm{III})$ was expected to oxidize to $\mathrm{Pu}(\mathrm{IV})$ due to $\mathrm{pH}$ adjustments under the SGW experimental conditions utilized, as will be further discussed in section 3.1.6. All RNs concentrations (expect for $\mathrm{Pu}$ ) were below the relative solubility limits in the carbonated SGW, according to literature ( $\mathrm{Np}(\mathrm{V})$ (Guillaumont and Mompean, 2003; Neck et al., 1992; Runde et al., 2002), Tc(VII) (Alliot et al., 2009), U(VI) and Pu(IV) (Huber et al., 2011), Th(IV) (Östhols et al., 1994)).

\subsection{Experimental conditions and procedure}

All experiments were performed at room temperature in a glove box under Ar atmosphere $(<1$ ppm $\mathrm{O}_{2}$ ). pH was measured with a semi micro Ross electrode (81-03, Orion Co.) in combination with a digital $\mathrm{pH}-$ meter (720A, Orion Co.). This set-up was calibrated using four commercial buffer solutions (Merck). The redox potentials in the clay dispersions were measured using an Orion 525A (Eh meter) and a Pt electrode combined with $\mathrm{Ag} / \mathrm{AgCl}$ reference system (Metrohm). Raw data were converted into Eh vs. standard hydrogen electrode (SHE) by correcting for the potential of the reference electrode. A commercial redox-buffer $(+220 \mathrm{mV}$, Schott instruments) was used for calibration. An equilibration time of 30 min was applied for all Eh measurements. Uncertainties in Eh measurements were \pm 50 mV (Altmaier et al., 2010; Kirsch et al., 2011).

Each batch adsorption sample was prepared in duplicate and contained $20 \mathrm{mg} / \mathrm{L}$ montmorillonite in a total volume of $50 \mathrm{~mL}$. For monitoring radionuclide adsorption, aliquots 
of the samples were taken after $72 \mathrm{~h}$ ( $\sim 3$ days), $260 \mathrm{~h}$ ( $\sim 2$ weeks), $580 \mathrm{~h}(\sim 1$ month) and 3800 $\mathrm{h}$ ( $\sim 6$ months). Initially, the top $0.5 \mathrm{~mL}$ of the sample was analysed by ICP-MS to obtain the amount of stable montmorillonite colloids in the dispersion. Thereafter, approximately $4 \mathrm{~mL}$ of each sample was transferred into ultra-centrifugation vials, sealed by welding inside the glove box and afterwards ultra-centrifuged (Beckman XL-90, rotor type 90Ti) for $1 \mathrm{~h}$ at $90.000 \mathrm{rpm}$ (centrifugal force of approximately $7 \cdot 10^{5} \times \mathrm{g}$ ). Subsequently, a volume of $0.5 \mathrm{~mL}$ of the ultra-centrifuged supernatants was sampled and analysed by ICP-MS. This ultracentrifugation procedure has been proven to effectively remove montmorillonite colloids and thereby the RNs associated to colloids (Altmaier et al., 2004). When the experiment ended (i.e. after 6 months), all samples were characterised by $\mathrm{pH}=8.9 \pm 0.3$ and $\mathrm{Eh}_{(\mathrm{SHE})}=+230 \pm$ $50 \mathrm{mV}$.

From the ICP-MS data, the distribution of RNs was calculated and defined as (i) the amount of soluble species RNs in dispersion (\%Free), (ii) RNs associated to montmorillonite colloids (\%Colloid) and (iii) the amount of RNs associated to particulates (i.e. settled particles, \%Part). This is illustrated in Figure 2. When present initially, 70\% of the FA was found free in the dispersion after fractionation. No distinction between soluble RNs species and dissolved FA-RN complexes could be made with this method. The concentration of RNs as soluble species was measured in the supernatant after ultra-centrifugation. Colloidal RN concentration was determined from the difference in concentration before and after ultracentrifugation. Particulate RNs was the remaining RN concentration based on the initial concentration. All results presented are mean values of duplicate samples with its standard deviation. The dispersion S3.5 was proved to have the same size distribution as $\mathrm{S} 3.5^{\mathrm{UC}}$. Identical adsorption results were obtained for these two dispersions, indicating a good reproducibility of the fractionation procedure developed (Norrfors et al., 2015).

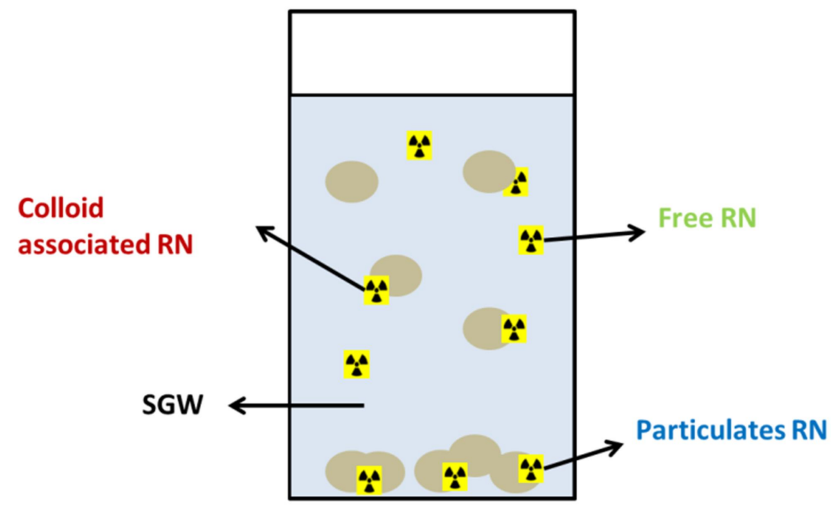


Figure 2: Schematic diagram of the radionuclide (RN) distribution in the batch adsorption samples, as determined from ICP-MS measurements.

$\mathrm{K}_{\mathrm{D}}$ values for each $\mathrm{RN}$ were calculated for the overall $\mathrm{RN}$ adsorption as "average $\mathrm{K}_{\mathrm{D}}$ values“, which does not distinguish between suspended (\%Colloids) and particulate (settled particles, $\%$ Part) clay. The expression for $\mathrm{K}_{\mathrm{D}}$ is given in equation 1 :

$K_{D}=\frac{[R N]_{T o t}-[R N]_{\text {free }}}{[R N]_{\text {free }}} \cdot \frac{1}{m_{\text {Clay }}}\left(\mathrm{dm}^{3} / \mathrm{kg}\right)$

where $[R N]_{\text {Tot }}$ and $m_{\text {Clay }}$ are the total, initial concentrations of RNs and montmorillonite, respectively. $[R N]_{\text {free }}$ is the concentration of soluble species of RNs in solution after a given equilibration time. A standard deviation of $\log \left(\mathrm{K}_{\mathrm{D}}\left(\mathrm{dm}^{3} / \mathrm{kg}\right)\right)=0.5$ was applied to all $\mathrm{K}_{\mathrm{D}}$ values, as suggested by Bradbury and Baeyens (Bradbury and Baeyens, 2011), due to experimental uncertainties for strongly adsorbing elements.

Additionally, with the mean amount of adsorption sites estimated for each clay dispersion, a $\mathrm{K}_{\mathrm{D}}$ value normalized to the amount of sites $\left(\mathrm{K}_{\mathrm{D} \text {,sites }}\right)$ was calculated. The relationship between the mass-normalized $\left(\mathrm{K}_{\mathrm{D}}\right)$, the sites-normalized values $\left(\mathrm{K}_{\mathrm{D} \text {,sites }}\right)$ and the amount of sites in one clay dispersion ([Sites]) is given by equation 2 :

$\log K_{D, \text { sites }}\left(\mathrm{dm}^{3} / \mathrm{mol}\right.$ of sorption sites $)=\log K_{D}\left(\mathrm{dm}^{3} / \mathrm{kg}\right)-\log [$ Sites $](\mathrm{mol} / \mathrm{kg})$

As mentioned above, the montmorillonite dispersions ( $\mathrm{S} 0$ and $\mathrm{S} 1$ ) containing the largest sized clay particles contain a mixture of colloidal sizes. In these dispersions, the larger clay particles sediment with time, whereas the smaller clay colloids will remain suspended. Therefore, a better evaluation of RN adsorption onto different colloid sizes could be made in these dispersions if the average $K_{D}$ value was compared to the $K_{D}$ value for the particulates (settled, large particles) in the clay dispersion, i.e. $\mathrm{K}_{\mathrm{D} \text {,part, }}$ defined as:

$$
K_{D, \text { part }}=\frac{[R N]_{\text {Tot }}-[R N]_{\text {free }}-[R N]_{\text {colloid }}}{[R N]_{\text {free }}} \cdot \frac{1}{m_{\text {part }}}\left(\mathrm{dm}^{3} / \mathrm{kg}\right)
$$

where $[R N]_{\text {colloid }}$ is the amount of RNs associated to stable, suspended clay colloids and $m_{\text {part }}$ the amount of clay particulates. 
Predominance diagrams were plotted with PhreePlot (Kinniburgh and Cooper, 2009), which contains an embedded version of the geochemical speciation program PHREEQC (Parkhurst and Appelo, 1999). Stability constants for dissolved species and solubility calculations were included in the NEA database (U/Np/Pu: (Guillaumont and Mompean, 2003), Tc: (Rard, 1999), Th: (Rand et al., 2009)). Fluoride and carbonate complexes for all RNs were considered in the calculations. However, at the present chemical conditions, the fluoride complexes did not play a significant role for the speciation. The formation constants of $\mathrm{Pu}(\mathrm{OH})_{2}\left(\mathrm{CO}_{3}\right)_{2}{ }^{2-}$ and $\mathrm{Np}(\mathrm{OH})_{2}\left(\mathrm{CO}_{3}\right)_{2}{ }^{2-}$ selected by THEREDA (Release 2013-08-02) were used in all calculations. The selected constants (in the NEA and THEREDA databases) were consistent with each other. The Davies equation was used for activity coefficient calculations. Reduction of sulfate and $\mathrm{CO}_{2}$ was not considered in the calculations.

The cation exchange capacity (CEC) was estimated to $0.87 \mathrm{eq} / \mathrm{kg}$ by Marques Fernandes et al. (Marques Fernandes et al., 2012). With the available adsorption constants, preliminary tests with all RNs showed that cation exchange reactions had no significant influence at $\mathrm{pH}$ 8.9. Consequently, cation exchange reactions were neglected in the present study.

To predict adsorption on natural clay rocks, Bradbury and Baeyens (Bradbury and Baeyens, 2011) applied a linear additive model (LAM). Their "bottom-up" approach describes the overall adsorption of an element to a complex mineral mixture as the sum of the amount adsorbed to each single type of mineral. For bentonite, they considered montmorillonite as the only adsorbent for radionuclides. In the present case, montmorillonite represents $75 \mathrm{wt} . \%$ of MX80 bentonite. Bradbury and Baeyens developed the 2 Site Protolysis Non Electrostatic Surface Complexation and Cation Exchange (2SPNE SC/CE) model for surface complexation and cation exchange reactions at montmorillonite surfaces (Bradbury and Baeyens, 2005; Bradbury and Baeyens, 2006). Two types of proton active sites were necessary to describe the titration data, but only one type was assumed to bind cations by the model approach. The cation binding sites consist of weak sites $\left([\equiv \mathrm{WOH}]=4 \cdot 10^{-2} \mathrm{~mol} / \mathrm{kg}\right)$ as well as less abundant strong sites $\left([\equiv \mathrm{SOH}]=2 \cdot 10^{-3} \mathrm{~mol} / \mathrm{kg}\right)$ with identical acid-base properties. Bradbury and Baeyens (Bradbury and Baeyens, 2005; Bradbury and Baeyens, 2006) determined surface complexation constants for $\mathrm{Np}(\mathrm{V}), \mathrm{U}(\mathrm{VI})$ and $\mathrm{Th}(\mathrm{IV})$ to strong sites of montmorillonite. Due to the low $\mathrm{RN}$ concentrations investigated in this study and the lack of $\mathrm{RN}$ surface complexation constants for the weak sites, only the strong sites were considered as adsorption 
sites. In solution, all RNs were predominately present as neutral or negative species due to complexation with $\mathrm{OH}^{-} / \mathrm{CO}_{3}{ }^{2-}$. Marques-Fernandez et al. (Marques Fernandes et al., 2012) determined thermodynamic constants for the formation of ternary montmorillonite-U(VI)carbonate surface complexes. Ternary montmorillonite- $\mathrm{Np}(\mathrm{V})$-carbonate surface complexes were not observed (Turner et al., 1998). Adsorption of $\mathrm{TcO}_{4}^{-}$to clays can be neglected (Guillaumont and Mompean, 2003; Ticknor et al., 1996).

Though added in oxidized form, $\mathrm{Np}(\mathrm{V})$ might be reduced to $\mathrm{Np}(\mathrm{IV})$ at the clay surface in line with work by Marsac et al. (Marsac et al., 2015) in the Np-illite system. Np(IV) adsorbs more strongly to minerals than the oxidized form. Surface complexation constants for Np(IV) are unknown for montmorillonite, but Bradbury and Baeyens (Bradbury and Baeyens, 2005; Bradbury and Baeyens, 2009) proposed linear free energy relationships (LFER) between cation hydrolysis constants (equation 4) and surface complexation constants (equation 5) for illite and montmorillonite within the 2SPNE SC/CE model.

$M^{n+}+x H_{2} O \rightleftharpoons M(O H)_{x}^{(n-x)}+H^{+}$, giving ${ }^{\mathrm{OH}} \mathrm{K}_{\mathrm{x}}$

$\equiv \mathrm{SOH}+M^{n+}+(x-1) H_{2} O \rightleftharpoons \equiv \operatorname{SOM}(\mathrm{OH})_{(x-1)}^{(n-x)}+x H^{+}$, giving ${ }^{\mathrm{S}} \mathrm{K}_{(\mathrm{x}-1)}$

The LFERs for montmorillonite (equation 6) and illite (equation 7) are:

$\log { }^{\mathrm{S}} \mathrm{K}_{(\mathrm{x}-1), \text { mont }}=8.1+0.90 \times \log { }^{\mathrm{OH}} \mathrm{K}_{\mathrm{X}}$

$\log { }^{\mathrm{S}} \mathrm{K}_{(\mathrm{x}-1), i l l}=7.9+0.83 \times \log { }^{\mathrm{OH}} \mathrm{K}_{\mathrm{x}}$

Uncertainties associated to the parameters of the LFERs were omitted for simplicity. According to Marsac et al. (Marsac et al., 2015) the formation of $\equiv \mathrm{SONp}(\mathrm{OH})_{4}{ }^{-}$was required to describe $\mathrm{Np}(\mathrm{IV})$ adsorption to illite. The same might be true for montmorillonite, as in the Th(IV) case (Bradbury and Baeyens, 2005). Unfortunately, the formation constant of $\equiv \mathrm{SOAn}(\mathrm{OH})_{4}{ }^{-}$cannot be estimated by a LFER since the formation constant for the corresponding aqueous species $\left(\mathrm{An}(\mathrm{OH})_{5}^{-}{ }_{(\mathrm{aq})}\right)$ was not available. Instead, the combination of equations 6 and 7 yielded an illite-montmorillonite LFER, which can be applied to Np(IV), using surface complexation constants determined by Marsac et al. (Marsac et al., 2015):

$\log \mathrm{S}_{(\mathrm{x}-1), \text { mont }}=1.08 \times \log \mathrm{S}_{(\mathrm{x}-1), \text { ill }}-0.46$ 
The $\mathrm{Np}$ (IV) constants were used for $\mathrm{Pu}(\mathrm{IV})$ because of their similar hydrolysis constants. By analogy with $\mathrm{Np}(\mathrm{IV}), \mathrm{U}(\mathrm{IV})$ and $\mathrm{Tc}(\mathrm{IV})$ surface complexes might form at the montmorillonite surface. However, given the lower redox potentials of the $\mathrm{U}(\mathrm{VI}) / \mathrm{U}(\mathrm{IV})$ and $\mathrm{Tc}(\mathrm{VII}) / \mathrm{Tc}(\mathrm{IV})$ couples compared to $\mathrm{Np}(\mathrm{V}) / \mathrm{Np}(\mathrm{IV})$, reduction of $\mathrm{U}(\mathrm{VI})$ or $\mathrm{Tc}(\mathrm{VII})$ was not expected at the relatively high Eh of our experiments. Thus, U(IV) and Tc(IV) adsorption to montmorillonite was not further considered.

Bradbury and Baeyens (Bradbury and Baeyens, 2005) showed that cations with different chemical behavior (related to their oxidation state) do not compete for the same adsorption sites, and have to be modelled by considering several types of binding sites for the different RNs. The different sites were given the same surface site density. The tetravalent RNs Th(IV), $\mathrm{Np}(\mathrm{IV})$ and $\mathrm{Pu}(\mathrm{IV})$ were expected to compete for the same strong sites. Applying the concept further, $\mathrm{Np}(\mathrm{V})$ and $\mathrm{U}(\mathrm{VI})$ have no competitor for their respective sites in our study. The natural occurrence of ${ }^{238} \mathrm{U}$, was not taken into account in the calculations, which apply only to the ${ }^{233} \mathrm{U}$ added to the clay dispersions. The surface complexation reactions and constants used in the modeling is presented in the Supporting Information (SIF -1), Table S1.

Our simulations were based on the estimations and assumptions discussed above. In addition, the impact of carbonates on the adsorption of most RNs onto clays has not been investigated. For instance, the potential formation of ternary carbonate-RN-surface complexes, as observed for U(IV) (Marques Fernandes et al., 2012) cannot be generally taken into account.

\section{Results and Discussion}

\subsection{Batch adsorption results}

\subsubsection{Stability of montmorillonite colloids}

The montmorillonite colloidal stability was followed via the evolution of the suspended Alconcentration at a given time, relative to the initial Al-concentration. The percentage of stable colloids for the different dispersions after 3 days, 2 weeks, 1 month and 6 months is shown in Figure 3. No significant sedimentation was observed after 3 days in any dispersion except in those containing larger montmorillonite colloids, i.e. S0 and S1. Here, a clear sedimentation was observed at longer times (e.g. only 55\% and $82 \%$ remain suspended after 6 months for the dispersions S0 and S1, respectively). In previous work (Norrfors et al., 2015), the long 
term stability of the undiluted clay dispersions were studied. In that study, $43 \%$ and $70 \%$ of the colloids remained stable in dispersions S0 and S1 after 2 months without shaking (Norrfors et al., 2015). Similar trends were found here even though the dispersions were diluted to $20 \mathrm{mg} / \mathrm{L}$. Interestingly, the colloidal dispersion obtained after sequential (ultra-) centrifugation (S3.5) and the dispersion obtained from one direct ultra-centrifugation step $\left(\mathrm{S} 3.5^{\mathrm{UC}}\right)$, have a similar size distribution (Norrfors et al., 2015), showing the same high colloidal stability (Figure 3).

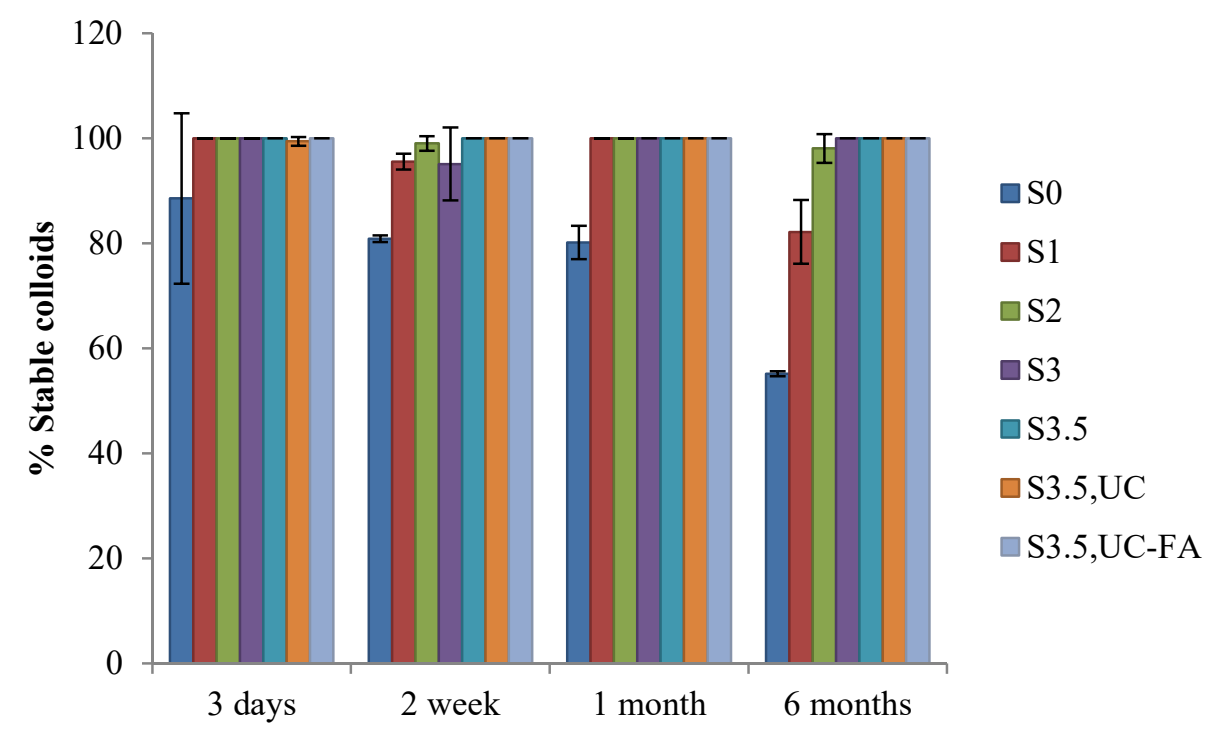

Figure 3: The amount of stable montmorillonite colloids in the seven clay dispersions (Table 1) as a function of time.

\subsubsection{Technetium adsorption}

Figure $4 \mathrm{a}$ shows the predominance $\mathrm{pH}$-Eh diagram for $\mathrm{Tc}$ in solution, calculated using Phreeplot. The $\mathrm{pH}$-Eh conditions measured at the end of the experiment (after 6 months, $\mathrm{pH}=$ $8.9 \pm 0.3$ and $\mathrm{Eh}=230 \pm 50 \mathrm{mV}$ ) are shown as a black square and were clearly in the stability field of $\mathrm{Tc}(\mathrm{VII})$ (i.e. $\mathrm{TcO}_{4}^{-}{ }_{(\mathrm{aq})}$ ). Based on this, no reduction of $\mathrm{Tc}(\mathrm{VII})$ to $\mathrm{Tc}(\mathrm{IV})$ was expected. In addition, no adsorption of Tc was expected due to the low solid to liquid ratio investigated and because of weak adsorption of $\mathrm{TcO}_{4}^{-}{ }_{(\mathrm{aq})}^{-}$onto mineral surfaces (Guillaumont and Mompean, 2003; Huber et al., 2011; Ticknor et al., 1996). Figure 4b presents the distribution of Tc between particulates, suspended colloids and soluble species for the S0 dispersion as a function of equilibration time. Similar results were obtained for all dispersions containing various clay size fractions, as presented in the Supporting Information (SIF -2, 
Figure S1). The concentration of Tc(VII) remains constant in solution up to 6 months for all dispersions (Figure $4 \mathrm{~b}$ and SIF -2, Figure S1). This supports the above statements that no reduction of technetium or adsorption onto clay colloids occurs within the analytical uncertainties, as expected from the speciation calculations. Slow reduction of $\mathrm{Tc}(\mathrm{VII})$ to Tc(IV) in presence of synthetic or Febex montmorillonite colloids has previously been noted in natural groundwater of similar low ionic strength $(\sim 1 \mathrm{mM})$ and $\mathrm{pH}=9$ after 1 month (Huber et al., 2015), which was related to the observed decrease in Eh to approximately -200 $\mathrm{mV}$ after 1 month.

Since most FA remains free in dispersion (section 2.4), no distinction between Tc-FA complexes and soluble species of Tc could be done and the Tc distribution in S3.5, S3.5 ${ }^{\mathrm{UC}, \mathrm{FA}}$ and $\mathrm{S} 3.5^{\mathrm{UC}}$ was identical, as expected (SIF -2, Figure S1).
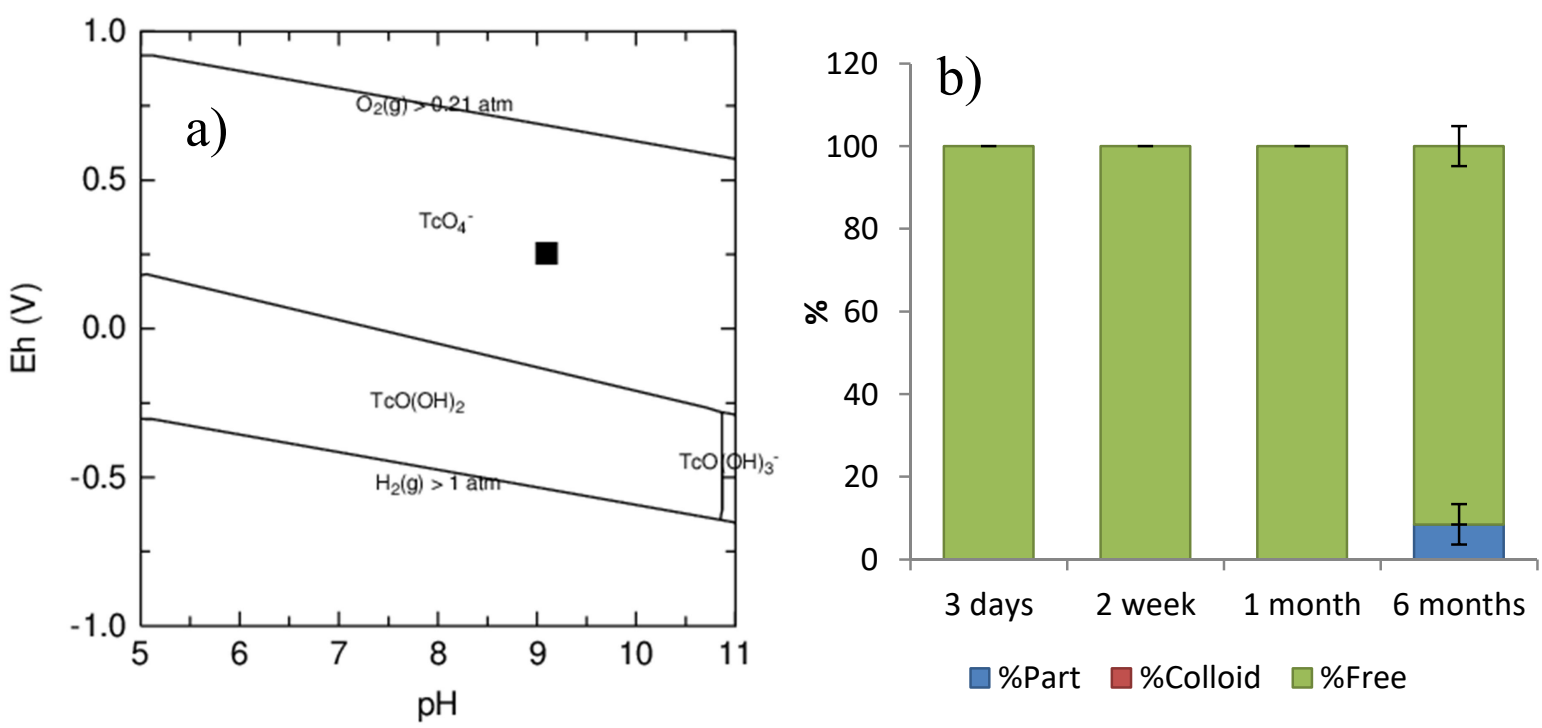

Figure 4: a) Predominance pH-Eh diagram for technetium where the chemical conditions in our study $(\mathrm{pH}=8.9$ and $\mathrm{Eh}=230 \mathrm{mV})$ are indicated by a black square. b) The distribution of Te, in percentage, between particulates (\%Part, blue), stable clay colloids (\%Colloid, red) or soluble species (\%Free, green) in the S0 dispersion is shown for different equilibration times. Histograms with the Tc distribution for the other clay dispersions are presented in the Supporting Information (SIF-2, Figure S1).

\subsubsection{Uranium adsorption}

In the $\mathrm{pH}$-Eh predominance diagram for uranium (Figure 5a) the present experimental conditions $(\mathrm{pH}=8.9 \pm 0.3$ and $\mathrm{Eh}=230 \pm 50 \mathrm{mV})$ are indicated by a black square. Due to the presence of carbonate in the $\mathrm{SGW}$, uranium should be mainly present as $\mathrm{UO}_{2}\left(\mathrm{CO}_{3}\right)_{3}{ }^{4-}$ (aq) . 
$\mathrm{U}(\mathrm{VI})$ is known to form highly soluble complexes with carbonate at $\mathrm{pH} 9$ (Bernhard et al., 2001; Bradbury and Baeyens, 2011; Hartmann et al., 2008; Marques Fernandes et al., 2012; Regenspurg et al., 2009). In previous studies (Marques Fernandes et al., 2012), a $\log \left(\mathrm{K}_{\mathrm{D}}\right.$ $\left.\left(\mathrm{dm}^{3} / \mathrm{kg}\right)\right)$ value of 2.7 was presented for $\mathrm{U}(\mathrm{VI})$ adsorption onto montmorillonite in $1 \mathrm{mM}$ $\mathrm{HCO}_{3}{ }^{-}$and $0.1 \mathrm{M} \mathrm{NaClO}_{4}$ at $\mathrm{pH}$ 9. This corresponds to an uptake of $1 \%$ uranium with our low clay concentration $(20 \mathrm{mg} / \mathrm{L})$. Our simulation for the SGW also predicts $\sim 1 \%$ uptake. In Figure $5 b$, the experimental uranium adsorption for dispersion $\mathrm{S} 0$ is presented as the distribution of $U$ between particulates, suspended colloids and soluble species as a function of equilibration time. The results for the other clay dispersions are presented in the Supporting Information (SIF -3, Figure S2). No uranium $\left({ }^{233} \mathrm{U}\right)$ adsorption onto montmorillonite was detected, within the experimental uncertainties, in any clay dispersions at any equilibration time. Instead, in line with published studies (Marques Fernandes et al., 2012) and model predictions, uranium remains as soluble carbonate complexes in all clay dispersions. Since FA does not strongly adsorb onto montmorillonite at $\mathrm{pH} 8.9$, the results for dispersion $\mathrm{S} 3.5^{\mathrm{UC}, \mathrm{FA}}$ were not expected to differ from those for dispersions in absence of FA, which agrees with the distribution presented (SIF -3, Figure S2).

Interestingly, a significant release of naturally occurring ${ }^{238} \mathrm{U}$ in the raw MX80 clay was observed in all dispersions (SIF-4, Figure S3). This was a consequence of the presence of carbonates in the SGW. This observation further strengthens the assumption that soluble Ucarbonate complexes were the favoured species under the present chemical conditions.
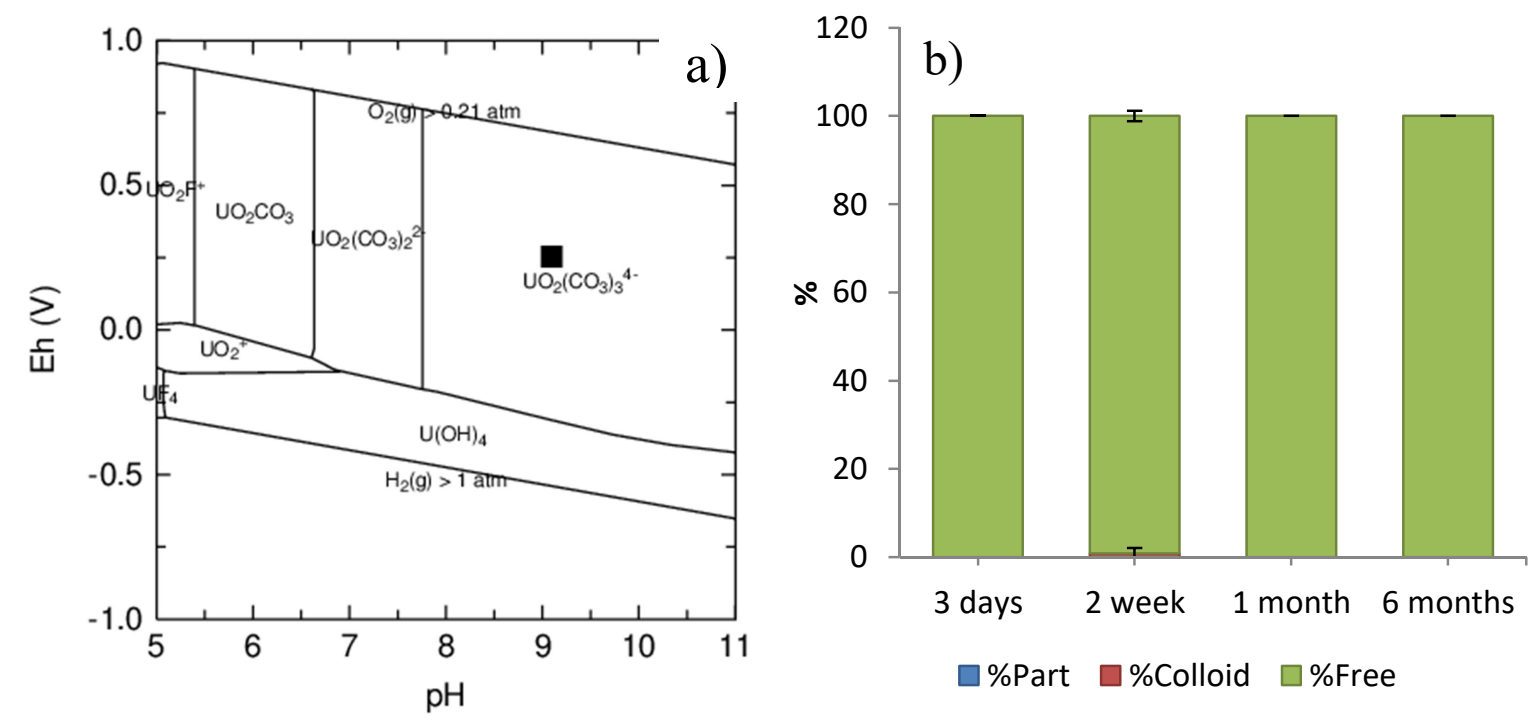
Figure 5: a) Predominance $\mathrm{pH}-\mathrm{Eh}$ diagram for uranium in the SGW, where the chemical conditions are indicated by a black square $(\mathrm{pH}=8.9$ and $\mathrm{Eh}=230 \mathrm{mV})$. b) The distribution of $\mathrm{U}$, in percentage, between particulates (\%Part, blue), stable clay colloids (\%Colloid, red) or soluble species (\%Free, green) in the S0 dispersion, shown for different equilibration times. The results obtained for the other clay dispersions are presented in the Supporting Information (SIF -3, Figure S2).

\subsubsection{Neptunium adsorption}

According to the $\mathrm{pH}-\mathrm{Eh}$ predominance diagram (Figure 6a), $\mathrm{Np}$ should prevail as $\mathrm{Np}(\mathrm{V})$ as $\mathrm{NpO}_{2} \mathrm{CO}_{3}{ }^{-}$in the $\mathrm{SGW}(\mathrm{pH}=8.9$ and $\mathrm{Eh}=230 \mathrm{mV})$ and remain in solution due to weak $\mathrm{Np}(\mathrm{V})$ uptake onto montmorillonite (Missana and Geckeis, 2006; Turner et al., 1998; Wu et al., 2009). The $\mathrm{Np}$ distribution in the $\mathrm{S} 0$ dispersion is presented in Figure $6 \mathrm{~b}$ for different equilibration times. The results for the other clay dispersions can be found in the Supporting Information (SIF -5, Figure S4). Overall, as expected, no Np uptake on montmorillonite was detected for any clay dispersion and equilibration time.

Recently, surface induced reduction of $\mathrm{Np}(\mathrm{V})$ to $\mathrm{Np}(\mathrm{IV})$ in the presence of illite has been evidenced (Marsac et al., 2015). Although $\mathrm{Np}(\mathrm{V})$ prevailed in solution, its reduction to $\mathrm{Np}$ (IV) was shown to be thermodynamically favoured at the illite surface due to strong $\mathrm{Np}(\mathrm{IV})$ adsorption. Structural Fe(II) in illite was suspected to be the redox partner, and $\mathrm{Fe}(\mathrm{II})$ is also present in our montmorillonite (Holmboe et al., 2012). Therefore, surface induced reduction of $\mathrm{Np}(\mathrm{V})$ to $\mathrm{Np}(\mathrm{IV})$ might also be relevant in the case of montmorillonite. Figure $6 \mathrm{c}$ shows the predicted percentage of $\mathrm{Np}$ uptake by montmorillonite as a function of Eh in the $\mathrm{SGW}$ at $\mathrm{pH}$ 8.9. For $\mathrm{Eh}<50 \mathrm{mV}, \mathrm{Np}$ (IV) prevails both at the surface and in solution, leading to nearly complete $\mathrm{Np}$ uptake by montmorillonite. For $\mathrm{Eh}>300 \mathrm{mV}, \mathrm{Np}(\mathrm{V})$ prevails both at the surface and in solution and no uptake was predicted. For $50<\mathrm{Eh}<300 \mathrm{mV}, \mathrm{Np}(\mathrm{V})$ prevails in solution whereas $\mathrm{Np}(\mathrm{IV})$ prevails at the surface, leading to an intermediate behaviour, which is highly sensitive to changes in Eh. The measured Eh $(+230 \mathrm{mV})$ is shown as a dashed line, with the experimental uncertainty $( \pm 50 \mathrm{mV})$, as dotted lines in Figure 6c. The model predicts an uptake of approximately $10 \% \mathrm{~Np}$ at $\mathrm{pH} 8.9$ and $\mathrm{Eh}_{(\mathrm{SHE})}=+230 \mathrm{mV}$. However, given the uncertainties in (i) the experimental Eh value and (ii) $\mathrm{Np}(\mathrm{IV}$ ) surface complexation constants reported in the 2 SPNE SC/CE model (Marsac et al., 2015), the experimental $\mathrm{Np}$ uptake was qualitatively consistent with the predictions. 
As for $\mathrm{U}$ and Tc, the presence of FA in $\mathrm{S} 3.5^{\mathrm{UC}, \mathrm{FA}}$ did not change the Np uptake as expected, since FA remains predominantly in solution (SIF -5, Figure S4).
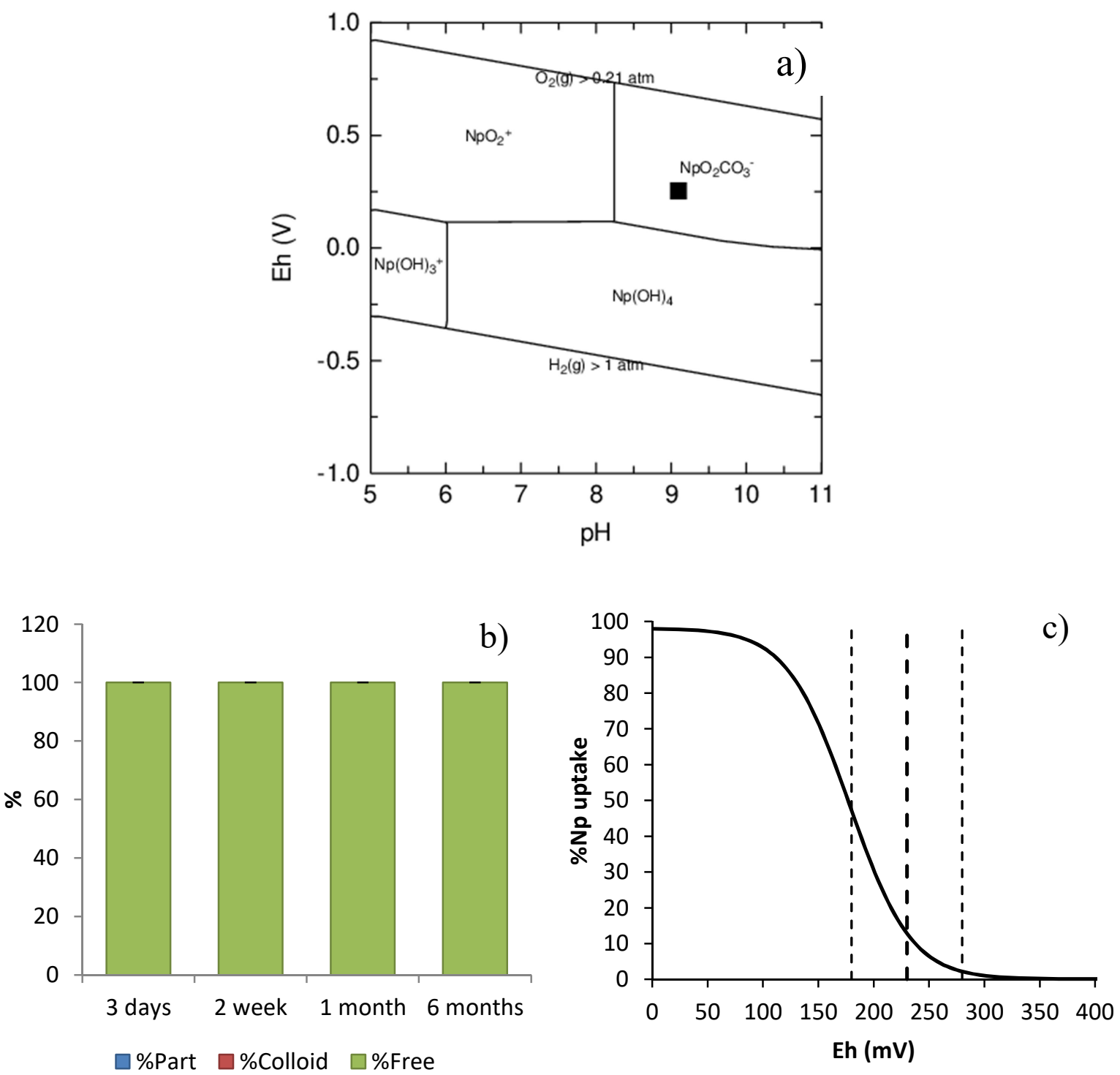

Figure 6: a) Predominance pH-Eh diagram for Np in the SGW. The black square corresponds to the present experimental conditions $(\mathrm{pH}=8.9$ and $\mathrm{Eh}=230 \mathrm{mV})$. b) Histograms presenting the distribution of neptunium, in percentage, between particulates (\%Part, blue), stable colloids (\%Colloid, red) or soluble species (\%Free, green) in the SO dispersion shown for different equilibration times. Histograms with the Np distribution for the other clay dispersions are presented in the Supporting Information (SIF -5, Figure S4). c) Predicted percentage uptake of Np by bentonite in the SGW as a function of Eh at $\mathrm{pH}$ 8.9. The experimental $\mathrm{Eh}(230 \pm 50 \mathrm{mV})$ is shown as dashed lines. 


\subsubsection{Thorium adsorption}

434

435

436

437

438

439

440

441

442

443

444

445

446

447

448

449

450

451

452

453

454

455

456

457

458

459

460

461

462

463

464

The Th speciation in the SGW is shown as a function of $\mathrm{pH}$ in Figure 7a. Th was predicted to be present as $\mathrm{Th}(\mathrm{OH})_{4(\mathrm{aq})}(60 \%)$ and $\mathrm{Th}(\mathrm{OH})_{2}\left(\mathrm{CO}_{3}\right)_{2}{ }^{2-}(40 \%)$ at $\mathrm{pH} 8.9$, marked as a vertical line in Figure 7a. Accordingly, the model predicts $83 \%$ of $\mathrm{Th}(\mathrm{IV})$ uptake onto montmorillonite, corresponding to $\log \left(\mathrm{K}_{\mathrm{D}}\left(\mathrm{dm}^{3} / \mathrm{kg}\right)\right)=5.4$. The distribution of $\mathrm{Th}$ in the $\mathrm{S} 0$ dispersion between particulates, suspended colloids or soluble species as a function of equilibration time is presented in Figure 7b. The results for the other clay dispersions are presented in the Supporting Information (SIF -6, Figure S5). Thorium was strongly adsorbed in all clay dispersions. The amount of settled Th increases with time in S0 (Figure 7b). This follows the increase in the amount of depositing clay particles, as already mentioned (Figure 3 ), pointing to the association of a fraction of Th with those unstable, large montmorillonite particulates. For the clay dispersions containing smaller sized colloids $\left(\mathrm{S} 2 \rightarrow \mathrm{S} 3.5^{\mathrm{UC}}\right)$, no sedimentation was expected which was in line with the experimental results, especially as small amounts of particulates found in all dispersions could rise from artefacts (e.g. adsorption to walls), as this fraction was not measured directly (but calculated from the total amount Th subtracting the measured amounts of Th in colloidal and aqueous phases).

The $K_{D}$ values calculated for Th in the different clay dispersions are presented as a function of equilibration time in Figure 7c. Data points for samples where the concentration of $\mathrm{Th}$ as soluble species were below the detection limit are not shown. Nevertheless, no significant variations in Th uptake was found. Overall, no kinetic effects were observed. Our $\log \left(\mathrm{K}_{\mathrm{D}}\right.$ $\left.\left(\mathrm{dm}^{3} / \mathrm{kg}\right)\right)=6.4 \pm 0.5$ were similar to those previously observed. $\log \left(\mathrm{K}_{\mathrm{D}}\left(\mathrm{dm}^{3} / \mathrm{kg}\right)\right)=6.4 \pm$ 0.5 and $\log \left(\mathrm{K}_{\mathrm{D}}\left(\mathrm{dm}^{3} / \mathrm{kg}\right)\right)=5.3 \pm 0.5$ for batch adsorption experiments were reported by Huber et al. (Huber et al., 2011; Huber et al., 2015) and Bouby et al. (Bouby et al., 2011), respectively, in a low ionic strength $(\sim 1 \mathrm{mM})$ groundwater at $\mathrm{pH}=8.3-9.5$ at carbonate concentrations of $\sim 0.05 \mathrm{mM}$, comparable to the SGW used in our study. The experimental $\mathrm{K}_{\mathrm{D}}$ value was slightly higher than expected from modelling (dashed line in Figure 7c). Nevertheless, the model for Th(IV) uptake was calibrated with the experimental results of Bradbury and Baeyens (Bradbury and Baeyens, 2005), involving a measured $\log \left(\mathrm{K}_{\mathrm{D}}\right.$ $\left.\left(\mathrm{dm}^{3} / \mathrm{kg}\right)\right) \approx 5.5$ for $\mathrm{Th}$ at $\mathrm{pH}=9$ in $0.1 \mathrm{M} \mathrm{NaClO}_{4}$, i.e. in higher ionic strength and in absence of carbonate.

In the montmorillonite dispersion obtained in presence of FA $\left(\mathrm{S} 3.5^{\mathrm{UC}, \mathrm{FA}}\right)$, the Th uptake onto clay colloids was significantly lower compared to the dispersions in absence of organic matter 
$\left(\mathrm{S} 3.5^{\mathrm{UC}}\right.$, Figure $7 \mathrm{c}$ and SIF -6, Figure S5). $\log \left(\mathrm{K}_{\mathrm{D}}\left(\mathrm{dm}^{3} / \mathrm{kg}\right)\right)$ was reduced to $5.3 \pm 0.5$ and 466 remains constant over time (Figure 7c). FA form complexes with Th(IV) which compete with 467 Th-montmorillonite surface complexes. This $K_{D}$ value corresponded to a decrease in the 468 amount of adsorbed Th by approximately 15\% (see histograms in the Supporting Information, SIF -6, Figure S5). Pan et al. (Pan et al., 2011) reported a decrease in $\log \left(\mathrm{K}_{\mathrm{D}}\left(\mathrm{dm}^{3} / \mathrm{kg}\right)\right)$ from 470 $\sim 6.0$ to $\sim 5.4$ after addition of FA in absence of carbonate, at $\mathrm{pH}=9$ and in $50 \mathrm{mM} \mathrm{NaCl}$, with 471 a FA to Na-bentonite ratio of 1:5 compared to 1:10 in our study. Yu et al. (Yu et al., 2008) 472 reported an even larger decrease in $\log \left(\mathrm{K}_{\mathrm{D}}\left(\mathrm{dm}^{3} / \mathrm{kg}\right)\right.$ ) value in presence of FA (from $\sim 5.2$ to $473 \sim 3.9)$ with a FA to bentonite ratio of $1: 30$ at $\mathrm{pH}=9$, at slightly higher ionic strength $(0.1 \mathrm{M}$ $474 \mathrm{NaNO}_{3}$ ). Therefore, the present results were in line with literature data.

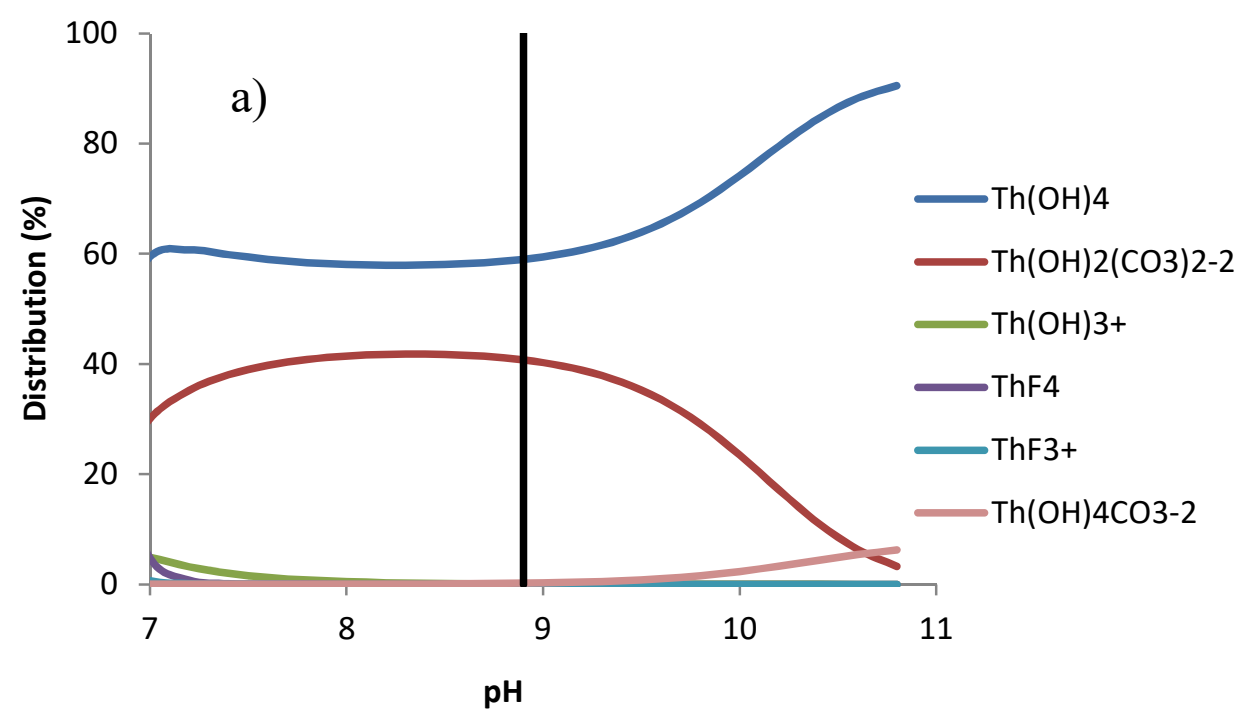

475

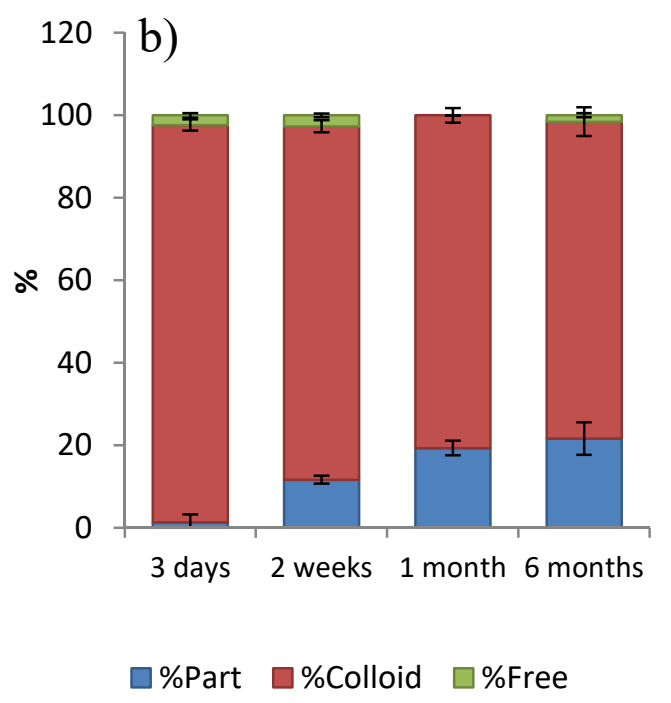




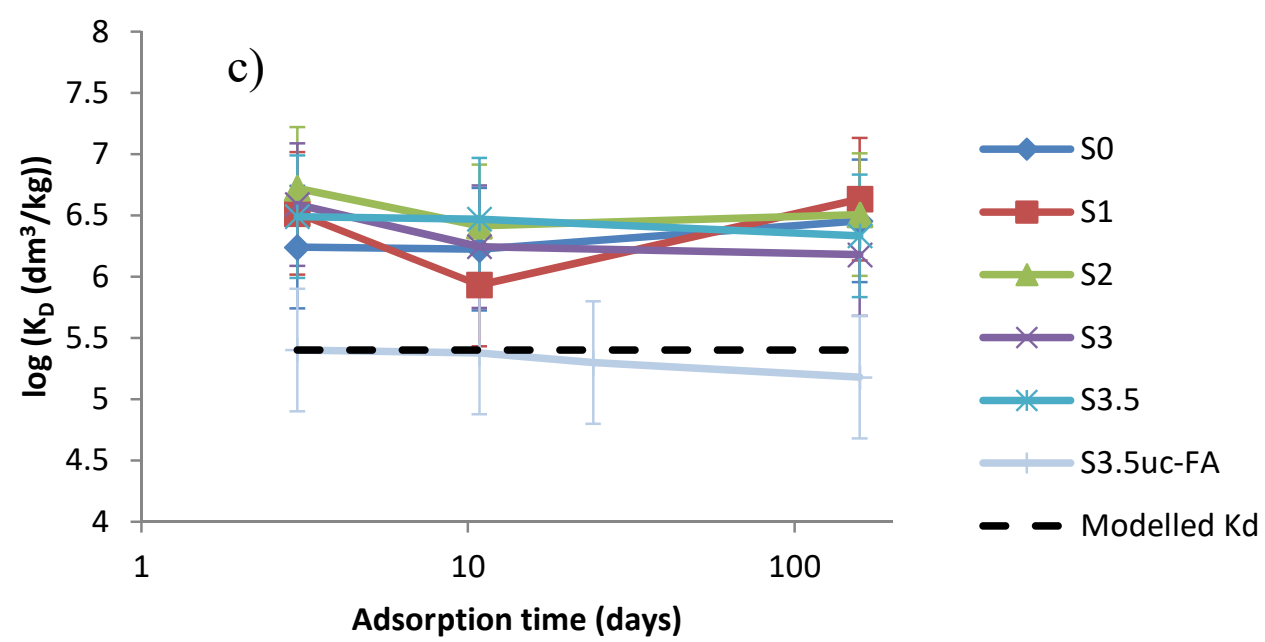

478

479

480

481

482

483

484

485

486

487

488

489

490

491

492

493

494

495

496

497

498

499

500

501

Figure 7: a) Species distribution diagram for thorium as a function of $\mathrm{pH}$ in the SGW. The experimental pH $=8.9$ is marked as a vertical line. b) Histograms presenting the distribution of Th, in percentage, between particulates (\%Part, blue), stable clay colloids (\%Colloid, red) or soluble species (\%Free, green) in the S0 dispersion, shown for different equilibration times. The results obtained for the other clay dispersion are presented in the Supporting Information (SIF -6, Figure S5). c) Adsorption of Th for all different sized montmorillonite dispersions, expressed as $\log \left(K_{D}\left(\mathrm{dm}^{3} / \mathrm{kg}\right)\right)$ values as a function of equilibration time. The dashed line corresponds to the predicted Th adsorption from modelling.

\subsubsection{Plutonium adsorption}

In the predominance $\mathrm{pH}$-Eh diagram for $\mathrm{Pu}$ (Figure 8a), the experimental conditions are marked by a black square $(\mathrm{pH}=8.9$ and $\mathrm{Eh}=230 \mathrm{mV})$. In the $\mathrm{SGW}, \mathrm{Pu}$ was expected to prevail as $\mathrm{Pu}(\mathrm{IV})$ mainly as $\mathrm{Pu}(\mathrm{OH})_{2}\left(\mathrm{CO}_{3}\right)_{2}{ }^{2-}{ }_{(\mathrm{aq})}$. $\mathrm{Pu}(\mathrm{IV})$ is known to adsorb strongly onto montmorillonite (Geckeis et al., 2004; Latrille et al., 2006; Lujanienè et al., 2007). Even though the total amount of $\mathrm{Pu}$ would exceed the solubility limit of $\mathrm{Pu}(\mathrm{IV})$ (Huber et al., 2011), the final aqueous $\mathrm{Pu}$ concentration was below the saturation with respect to $\mathrm{PuO}_{2 \text { (am,hydr) }}$ because of the strong adsorption of $\mathrm{Pu}$ onto montmorillonite. Furthermore, since adsorption is usually a faster process than nucleation and precipitation, precipitation of $\mathrm{Pu}$ was not expected (Zhao et al., 2011). An uptake of 97\% Pu(IV) was predicted by the model. This was consistent with the simulated Np uptake at Eh $<50 \mathrm{mV}$ (see Figure 6c), where Np(IV) would prevail both at the surface and in solution. A Pu uptake of $97 \%$ corresponds to $\log \left(\mathrm{K}_{\mathrm{D}}\right.$ $\left.\left(\mathrm{dm}^{3} / \mathrm{kg}\right)\right)=6.3$ in our experimental conditions.

The distribution of $\mathrm{Pu}$ as a function of equilibration time is presented for the clay dispersion $\mathrm{S} 0$ in Figure $8 \mathrm{~b}$. Pu was largely associated to montmorillonite. The distribution of $\mathrm{Pu}$ in the 
other clay dispersions is presented in the Supporting Information and was comparable to the results found for S0 (SIF -7, Figure S6 and Figure 8b). As for Th, some Pu is associated to particulates present in the clay dispersions with the largest colloids (i.e. S0 and S1) which is seen over time). This was explained by sedimentation of larger montmorillonite particles (see Figure 3). In the dispersion with smaller colloids, no $\mathrm{Pu}$ particulates were found (SIF -7, Figure $\mathrm{S} 6$ ). $\mathrm{K}_{\mathrm{D}}$ values for $\mathrm{Pu}$ adsorption to each clay suspension are presented as a function of equilibration time in Figure 8c. Pu uptake does not significantly evolve over the first month, with an average distribution coefficient for all dispersions of $\log \left(\mathrm{K}_{\mathrm{D}}\left(\mathrm{dm}^{3} / \mathrm{kg}\right)\right)=5.7 \pm 0.5$. Although, the $\mathrm{Pu}(\mathrm{IV})$ surface complexation constants for the 2 SPNE SC/CE model used in this study were based on several approximations, the predicted $\log \left(\mathrm{K}_{\mathrm{D}}\left(\mathrm{dm}^{3} / \mathrm{kg}\right)\right)=6.3$ (dashed line in Figure 8c) agrees well with the experimental data. High uptake of Pu show that $\mathrm{Pu}(\mathrm{IV})$ predominated in the SGW. However, the uptake was slightly lower than for Th (Figure 7c) and the slight increase in uptake of Pu over time (almost insignificant given the error bars) might suggest the presence of a small fraction of $\mathrm{Pu}(\mathrm{III})$, as present initially, which took time to oxidize to $\mathrm{Pu}(\mathrm{IV})$. After 6 months equilibration time, the uptake of $\mathrm{Pu}$ was similar to those reported for $\mathrm{Th}$ and those predicted from the model. They indicate a consistent high adsorption of the two tetravalent RNs. Previous studies (Geckeis et al., 2004; Huber et al., 2015) reported $\log \left(\mathrm{K}_{\mathrm{D}}\left(\mathrm{dm}^{3} / \mathrm{kg}\right)\right)=5.4 \pm 0.5$ and $\log \left(\mathrm{K}_{\mathrm{D}}\left(\mathrm{dm}^{3} / \mathrm{kg}\right)\right)=6.4 \pm 0.5$ in ground waters of low ionic strength $(\sim 1 \mathrm{mM})$ and $\mathrm{pH}=9.5-9.6$ for adsorption of $\mathrm{Pu}(\mathrm{IV})$ to montmorillonite. These values were consistent with the present work despite higher Eh in our study ( 0 to $-200 \mathrm{mV}$ in (Geckeis et al., 2004; Huber et al., 2015)), due to the large stability field of $\mathrm{Pu}(\mathrm{IV})$ at $\mathrm{pH} \approx 9$.

As for $\mathrm{Th}$, we observe a lower $\mathrm{Pu}$ uptake onto the clay in the $\mathrm{S} 3.5^{\mathrm{UC}, \mathrm{FA}}$ dispersion since $\mathrm{FA}$ was acting as a competing ligand (Figure 8c). Pu adsorption in the presence of FA remained constant at $\log \left(\mathrm{K}_{\mathrm{D}}\left(\mathrm{dm}^{3} / \mathrm{kg}\right)\right)=5.1 \pm 0.5$. In previous published work, the reported competitive effect of added FA differs. Thus, Ticknor et al. (Ticknor et al., 1996) investigated $\mathrm{Pu}$ uptake by montmorillonite $\left([\mathrm{Pu}(\mathrm{IV})]=1.1 \cdot 10^{-10} \mathrm{M}, \mathrm{m} / \mathrm{V}=25 \mathrm{~g} / \mathrm{L}\right)$ in the presence of $\mathrm{FA}$ $(0-4.84 \mathrm{mg} / \mathrm{L})$ at $\mathrm{pH}=7.7$, with $56 \mathrm{mg} / \mathrm{L} \mathrm{HCO}_{3}$ and an ionic strength of $\sim 0.2 \mathrm{M}$, and observed a maximum decrease in $\log \left(\mathrm{K}_{\mathrm{D}}\left(\mathrm{dm}^{3} / \mathrm{kg}\right)\right)$ from $\sim 4.8$ to $\sim 3.5$, even though their FA to montmorillonite ratio was far less than in our study. On the opposite, Boggs et al. (Boggs et al., 2015) did not find any effect of FA addition at $\mathrm{pH}=8$ in $0.01 \mathrm{M} \mathrm{NaCl}$. In that study, the FA to montmorillonite ratio was higher $\left(\mathrm{m} / \mathrm{V}=0.1 \mathrm{~g} / \mathrm{L},[\mathrm{FA}]=1.5 \mathrm{mg} / \mathrm{L},[\mathrm{Pu}(\mathrm{IV})]=10^{-10}\right.$ $\mathrm{M})$. A decrease in $\mathrm{Pu}$ adsorption was expected under our conditions as suggested by the Th 


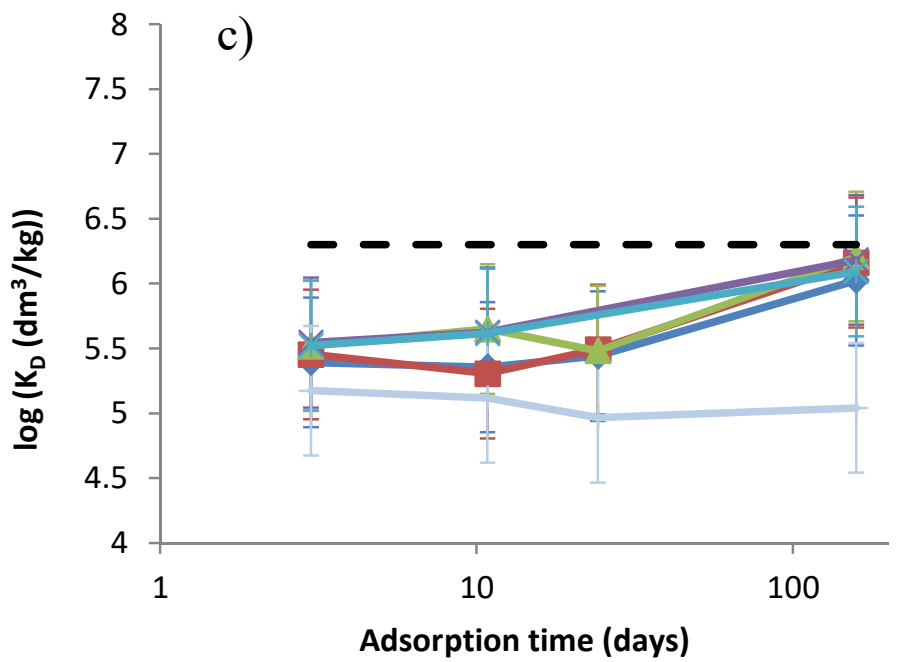

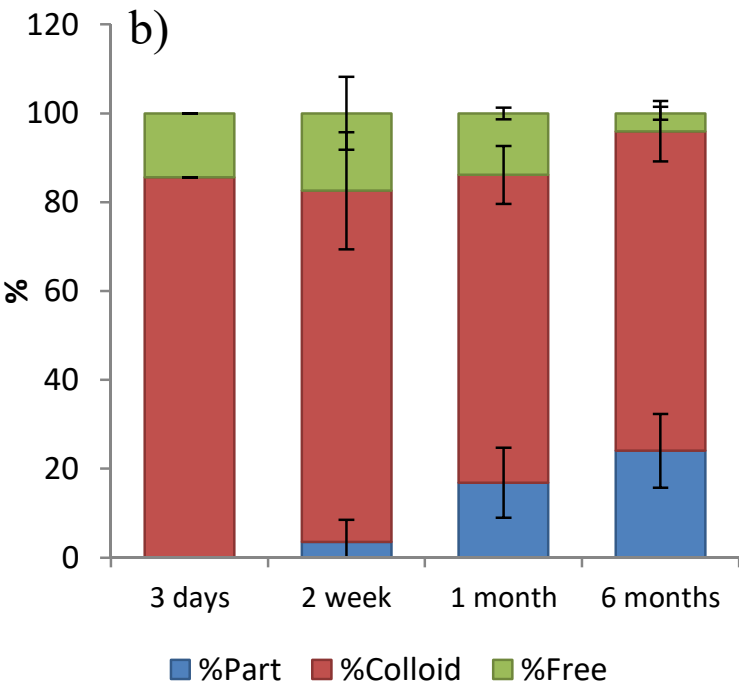

$\longrightarrow$ so

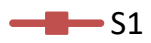

$\longrightarrow$ S2

S3

米 S3.5

S3.5uc-FA

- Modelled Kd

Figure 8: a) Predominance pH-Eh diagram for Pu in the SGW. The experimental conditions are marked by a black square $(\mathrm{pH}=8.9$ and $\mathrm{Eh}=230 \mathrm{mV})$. b) Histograms presenting the distribution of $\mathrm{Pu}$, in percentage, between particulates (\%Part, blue), stable clay colloids (\%Colloid, red) or soluble species (\%Free, green) in the S0 dispersion, shown for different equilibration times. The results obtained for the other clay dispersions are presented in the Supporting Information (SIF -7, Figure S6). c) Adsorption of Pu for all different sized montmorillonite dispersions, expressed as $\log \left(K_{\mathrm{D}}\left(\mathrm{dm}^{3} / \mathrm{kg}\right)\right)$ values as a function of equilibration time. The dashed line corresponds to the predicted Pu adsorption from modelling. 


\subsection{Discussion of colloidal size effect on adsorption of RNs onto montmorillonite}

550 The present batch adsorption results do not suggest that any of the tested clay colloid

551

552

553

554

555

556

557

558

559

560

561

562

563

564

565

566

567

568

569

570

571

572

573

574

575

576

577

578

579 dispersions particularly favour adsorption of $\mathrm{Th}(\mathrm{IV})$ and $\mathrm{Pu}(\mathrm{IV})$, within the analytical uncertainties (see Figures $7 \mathrm{c}$ and $8 \mathrm{c}$ where the uptake of $\mathrm{Th}$ and $\mathrm{Pu}$ was normalized to the mass of montmorillonite and expressed as $\log \mathrm{K}_{\mathrm{D}}$ according to equation 1). To better compare the amount of adsorbed RNs, the estimated amounts of edge sites were calculated by assuming disc-shaped particles with a given mean particle size (Norrfors et al., 2015). The estimates for each clay dispersion are included in Table 1, which suggests an increase by a factor of approximately six in the amount of sites (corresponding to both weak and strong sites according to the 2 SPNE SC/CE model) between the dispersions containing all the clay particle sizes (S0) and those more restricted to smaller sizes $\left(\mathrm{S} 3.5^{\mathrm{UC}}\right)$. Based on these estimations, a factor six difference in the amount of adsorbed RNs could be expected. $\mathrm{K}_{\mathrm{D}}$ values normalized to the amount of sites $\left(\mathrm{K}_{\mathrm{D} \text {,sites }}\right)$, instead of mass, could be calculated using equation 2. This yielded a maximal theoretical difference of $\log (6)=0.8$ units between the two dispersions S0 and S3.5. Nevertheless, this value was similar to the experimental uncertainty ( \pm 0.5 units) for $\log K_{D}$ measurements, and could explain why no significant difference in adsorption between the clay dispersions could be detected in our study.

To better compare the adsorption onto smaller and larger clay colloids, $K_{D}$ values for the montmorillonite pertaining to the particulate phase $\left(\mathrm{K}_{\mathrm{D} \text {,part }}\right.$, for the larger particles) were

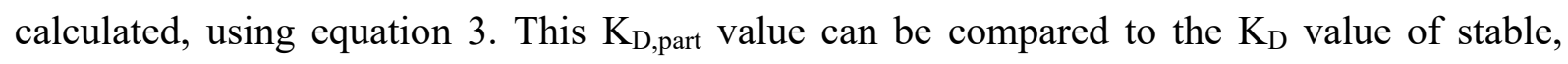
suspended montmorillonite colloids (corresponding to smaller colloids). All clay dispersions were polydisperse and in the dispersions with the largest sized colloids, the smaller sized colloids were present as well. From the amount of settled colloids (Figure 3), compared to the amount of Th in the particulate phase in dispersion S0 after 6 months (Figure 7b), a log $\left(\mathrm{K}_{\mathrm{D} \text {,part }}\left(\mathrm{dm}^{3} / \mathrm{kg}\right)\right)=6.2 \pm 0.5$ was obtained. This was similar to $\log \left(\mathrm{K}_{\mathrm{D}}\left(\mathrm{dm}^{3} / \mathrm{kg}\right)\right)=6.3 \pm 0.5$ obtained for the smaller, stable dispersion S3.5, within the experimental uncertainties. Consequently, the amount of adsorbed Th was similar for both clay dispersions and no difference in $K_{D}$ values related to the mean colloidal size in the clay dispersions could be inferred.

To summarize, no significant differences between adsorption of strongly adsorbing RNs onto the smallest and largest sized montmorillonite colloids could be deduced, so that an "average 
$\log \left(\mathrm{K}_{\mathrm{D}}\right)$ " should provide sufficient estimates for $\mathrm{RN}$ adsorption to bentonites. This "average $\log \left(\mathrm{K}_{\mathrm{D}}\right)$ " can be used in reactive transport modelling with confidence, which simplifies models for RN migration accordingly. To better study a potential effect of colloidal size, one may recommend the use of RNs which adsorb to clays stronger than penta- hexa- and heptavalent RNs but weaker than tetravalent RNs.

While an ultimate statement concerning desorption properties related to the mean colloidal (particle) size for the added RNs cannot be made, an effect did occur for natural ${ }^{238} \mathrm{U}$ which varied significantly with the clay dispersion properties (see Supporting Information, SIF-4).

\section{Conclusions}

In this work, experiments were performed on $\mathrm{RN}$ uptake onto size separated montmorillonite colloids. $\mathrm{Np}(\mathrm{V}), \mathrm{Tc}(\mathrm{VII})$ and $\mathrm{U}(\mathrm{VI})$ were found not to adsorb onto montmorillonite under the present experimental conditions. Instead, they were present as soluble species, mainly as $\mathrm{NpO}_{2} \mathrm{CO}_{3}{ }_{(\mathrm{aq})}^{-}, \mathrm{TcO}_{4}{ }_{(\mathrm{aq})}^{-}$and $\mathrm{UO}_{2}\left(\mathrm{CO}_{3}\right)_{3}{ }^{4-}$ (aq) , respectively. On the contrary, $\mathrm{Th}(\mathrm{IV})$ and $\mathrm{Pu}(\mathrm{IV})$ strongly adsorb onto montmorillonite. If fulvic acids are present (as here during the fractionation step of the clay colloids and after the dilution of their dispersions), the amount $\mathrm{Pu}$ and $\mathrm{Th}$ associated with clay was significantly decreased. During the experimental observation period (up to 6 months), larger clay particles settled with time. A part of Th and $\mathrm{Pu}$ were adsorbed and remain adsorbed on these larger, unstable montmorillonite particles (i.e. in the particulate phase). All experimental results were in line with model predictions.

No difference in adsorption behaviour of $\mathrm{Th}$ and $\mathrm{Pu}$ onto different sized clay colloids, expressed as mass-normalized $\mathrm{K}_{\mathrm{D}}$ values, was found. Between the clay dispersions with smallest and the largest mean colloidal sizes, an estimated difference by a factor of six in the amounts of edge sites was calculated. This was too small to be detectable within the experimental uncertainties. Therefore, based on the experimental results for MX-80 presented here, it seems to be valid to implement an "average log $\mathrm{K}_{\mathrm{D}}$ " for all colloidal sizes in reactive transport modelling codes.

While a variation in the montmorillonite colloidal size does not seem to influence the adsorption behaviour of strongly adsorbing RNs, the question remains if it affects $\mathrm{RN}$ desorption and desorption kinetics. This is presently investigated in a separate study. 


\section{Acknowledgements}

612 The Swedish Nuclear Fuel and Waste Management Co. (SKB) is gratefully acknowledged for 613 generous financial support. This work is a part of the project CP-BELBaR Fission 2010-1.1.1. 614 This work has been supported by the European FP7 TALISMAN (Transnational Access to 615 Large Infrastructure for a Safe Management of ActiNide) project under the grant agreement \# 616 323300; JRP no TALI-C02-10. The authors gratefully acknowledge C. Walschburger 617 (Institute for Nuclear Waste Disposal) for laboratory work and analytical support. 


\section{References}

619

620

621

622

623

624

625

626

627

628

629

630

631

632

633

634

635

636

637

638

639

640

641

642

643

644

THEREDA, Thermodynamic Reference Database. Release 2013-08-02. .

Alliot, I., Alliot, C., Vitorge, P., Fattahi, M., 2009. Speciation of Technetium(IV) in Bicarbonate Media. Environmental Science \& Technology 43, 9174-9182.

Altmaier, M., Gaona, X., Fellhauer, D., Buckau, G., 2010. Intercomparison of redox determination methods on designed and near-neutral aqueous systems; KIT-SR 7572. Karlsruhe Institute of Technology, Karlsruhe 34.

Altmaier, M., Neck, V., Fanghänel, T., 2004. Solubility and colloid formation of Th(IV) in concentrated $\mathrm{NaCl}$ and $\mathrm{MgCl} 2$ solution, Radiochimica Acta/International journal for chemical aspects of nuclear science and technology, p. 537.

Bernhard, G., Geipel, G., Reich, T., Brendler, V., Amayri, S., Nitsche, H., 2001. Uranyl(VI) carbonate complex formation: Validation of the Ca2UO2(CO3)3(aq.) species. Radiochim. Acta 89, 511-518.

Boggs, M.A., Dai, Z., Kersting, A.B., Zavarin, M., 2015. Plutonium(IV) sorption to montmorillonite in the presence of organic matter. Journal of Environmental Radioactivity $141,90-96$.

Bouby, M., Geckeis, H., Lutzenkirchen, J., Mihai, S., Schafer, T., 2011. Interaction of bentonite colloids with $\mathrm{Cs}, \mathrm{Eu}, \mathrm{Th}$ and $\mathrm{U}$ in presence of humic acid: A flow field-flow fractionation study. Geochim. Cosmochim. Acta 75, 3866-3880.

Bradbury, M.H., Baeyens, B., 2005. Modelling the sorption of Mn(II), Co(II), Ni(II), Zn(II), $\mathrm{Cd}(\mathrm{II}), \mathrm{Eu}(\mathrm{III}), \mathrm{Am}(\mathrm{III}), \mathrm{Sn}(\mathrm{IV}), \mathrm{Th}(\mathrm{IV}), \mathrm{Np}(\mathrm{V})$ and U(VI) on montmorillonite: Linear free energy relationships and estimates of surface binding constants for some selected heavy metals and actinides. Geochim. Cosmochim. Acta 69, 875-892.

Bradbury, M.H., Baeyens, B., 2006. Modelling sorption data for the actinides Am(III), Np(V) and $\mathrm{Pa}(\mathrm{V})$ on montmorillonite. Radiochim. Acta 94, 619-625.

Bradbury, M.H., Baeyens, B., 2009. Sorption modelling on illite. Part II: Actinide sorption and linear free energy relationships. Geochim. Cosmochim. Acta 73, 1004-1013. 
645 Bradbury, M.H., Baeyens, B., 2011. Predictive sorption modelling of Ni(II), Co(II), Eu(IIII), 646 Th(IV) and U(VI) on MX-80 bentonite and Opalinus Clay: A "bottom-up" approach. Applied 647 Clay Science 52, 27-33.

648 Bradford, S.A., Yates, S.R., Bettahar, M., Simunek, J., 2002. Physical factors affecting the 649 650 transport and fate of colloids in saturated porous media. Water Resources Research 38, 63-6163-12.

651 Geckeis, H., Schäfer, T., Hauser, W., Rabung, T., Missana, T., Degueldre, C., Möri, A., 652 Eikenberg, J., Fierz, T., Alexander, W.R., 2004. Results of the colloid and radionuclide 653 retention experiment (CRR) at the Grimsel Test Site (GTS), Switzerland - impact of reaction 654 kinetics and speciation on radionuclide migration. Radiochim. Acta 92, 765-774.

655 Guillaumont, R., Mompean, F.J., 2003. Update on the chemical thermodynamics of uranium, 656 neptunium, plutonium, americium and technetium, in: Mompean, F.J., Illemassene, M., 657 Domenech-Orti, C., Said, K.B. (Eds.). OECD Nuclear Energy Agency, Data Bank, Issy-les658 Moulineaux, France.

659 Hartmann, E., Geckeis, H., Rabung, T., Lützenkirchen, J., Fanghänel, T., 2008. Sorption of 660 radionuclides onto natural clay rocks, Radiochimica Acta International journal for chemical 661 aspects of nuclear science and technology, p. 699.

662 Holmboe, M., Jonsson, M., Wold, S., 2012. Influence of $\gamma$-radiation on the reactivity of 663 montmorillonite towards H2O2. Radiation Physics and Chemistry 81, 190-194.

664 Huber, F., Kunze, P., Geckeis, H., Schäfer, T., 2011. Sorption reversibility kinetics in the 665 ternary system radionuclide-bentonite colloids/nanoparticles-granite fracture filling material. 666 Applied Geochemistry 26, 2226-2237.

667 Huber, F.M., Heck, S., Truche, L., Bouby, M., Brendle, J., Hoess, P., Schafer, T., 2015. 668 Radionuclide desorption kinetics on synthetic $\mathrm{Zn} / \mathrm{Ni}$-labeled montmorillonite nanoparticles. 669 Geochim. Cosmochim. Acta 148, 426-441.

670 Jennings, B.R., 1993. Size and thickness measurement of polydisperse clay samples. Clay 671 Minerals 28, 485-494. 
672 Jennings, B.R., Parslow, K., 1988. Particle Size Measurement: The Equivalent Spherical 673 Diameter. Proceedings of the Royal Society of London. A. Mathematical and Physical 674 Sciences 419, 137-149.

675 Karnland, O., Olsson, S., Nilsson, U., 2006. Mineralogy and sealing properties of various 676 bentonites and smectite-rich clay materials. SKB internal report TR-06-30.

677 Kinniburgh, D.G., Cooper, D.M., 2009. PhreePlot: Creating graphical output with 678 PHRREQC.

679 Kirsch, R., Fellhauer, D., Altmaier, M., Neck, V., Rossberg, A., Fanghänel, T., Charlet, L., 680 Scheinost, A.C., 2011. Oxidation State and Local Structure of Plutonium Reacted with 681 Magnetite, Mackinawite, and Chukanovite. Environmental Science \& Technology 45, 72676827274.

683 Kunze, P., Seher, H., Hauser, W., Panak, P.J., Geckeis, H., Fanghänel, T., Schäfer, T., 2008. 684 The influence of colloid formation in a granite groundwater bentonite porewater mixing zone 685 on radionuclide speciation. Journal of Contaminant Hydrology 102, 263-272.

686 Latrille, C., Ly, J., Herbette, M., 2006. Retention of Sn(IV) and Pu(IV) onto four argillites 687 from the Callovo-Oxfordian level at Bure (France) from eight equilibrated sedimentary 688 waters, Radiochim. Acta, p. 421.

689 Lujanienè, G., Motiejūnas, S., Šapolaitè, J., 2007. Sorption of Cs, Pu and Am on clay 690 minerals. J. Radioanal. Nucl. Chem. 274, 345-353.

691 Madden, A.S., Hochella, M.F., Luxton, T.P., 2006. Insights for size-dependent reactivity of 692 hematite nanomineral surfaces through $\mathrm{Cu} 2+$ sorption. Geochim. Cosmochim. Acta 70, 40956934104.

694 Marques Fernandes, M., Baeyens, B., Dähn, R., Scheinost, A.C., Bradbury, M.H., 2012. $695 \mathrm{U}(\mathrm{VI})$ sorption on montmorillonite in the absence and presence of carbonate: A macroscopic 696 and microscopic study. Geochim. Cosmochim. Acta 93, 262-277.

697 Marsac, R., Banik, N.1., Lützenkirchen, J., Marquardt, C.M., Dardenne, K., Schild, D., Rothe, 698 J., Diascorn, A., Kupcik, T., Schäfer, T., Geckeis, H., 2015. Neptunium redox speciation at 699 the illite surface. Geochim. Cosmochim. Acta 152, 39-51. 
Missana, T., Alonso, Ú., Turrero, M.J., 2003. Generation and stability of bentonite colloids at the bentonite/granite interface of a deep geological radioactive waste repository. Journal of Contaminant Hydrology 61, 17-31.

Missana, T., Geckeis, H., 2006. Grimsel Test Site - Investigation Phase V. The CRR Final Project Report Series II: Supporting Laboratory Experiments with Radionuclides and Bentonite Colloids NAGRA Technical Report Series NTB 03-02.

Möri, A., Alexander, W.R., Geckeis, H., Hauser, W., Schafer, T., Eikenberg, J., Fierz, T., Degueldre, C., Missana, T., 2003. The colloid and radionuclide retardation experiment at the Grimsel Test Site: influence of bentonite colloids on radionuclide migration in a fractured rock. Colloids and Surfaces a-Physicochemical and Engineering Aspects 217, 33-47.

Neck, V., Kim, J.I., Kanellakopulos, B., 1992. Solubility and Hydrolysis Behaviour of Neptunium(V). Radiochimca Acta 56, 25-30.

Norrfors, K.K., Bouby, M., Heck, S., Finck, N., Marsac, R., Schäfer, T., Geckeis, H., Wold, S., 2015. Montmorillonite colloids: I. Characterization and stability of dispersions with different size fractions. Applied Clay Science 114, 179-189.

Pan, D.-Q., Fan, Q.-H., Li, P., Liu, S.-P., Wu, W.-S., 2011. Sorption of Th(IV) on Nabentonite: Effects of $\mathrm{pH}$, ionic strength, humic substances and temperature. Chemical Engineering Journal 172, 898-905.

Parkhurst, D.L., Appelo, C.A.J., 1999. User's guide to PHREEQC (version 2). US Geol. Surv. Water Resour. Inv. Rep. 99-4259, 312p. .

Rand, R., Fuger, J., Neck, V., Grenthe, I., Rai, D., 2009. Chemical Thermodynamics of Thorium, Chemical Thermodynamics, vol. 11. OECD Publishing

Rard, J.A., 1999. Chemical thermodynamics of technetium. North Holland.

Regenspurg, S., Schild, D., Schäfer, T., Huber, F., Malmström, M.E., 2009. Removal of uranium(VI) from the aqueous phase by iron(II) minerals in presence of bicarbonate. Applied Geochemistry 24, 1617-1625.

Runde, W., Conradson, S.D., Wes Efurd, D., Lu, N., VanPelt, C.E., Tait, C.D., 2002. Solubility and sorption of redox-sensitive radionuclides $(\mathrm{Np}, \mathrm{Pu})$ in $\mathrm{J}-13$ water from the 
Yucca Mountain site: comparison between experiment and theory. Applied Geochemistry 17, 837-853.

Schäfer, T., Huber, F., Seher, H., Missana, T., Alonso, U., Kumke, M., Eidner, S., Claret, F., Enzmann, F., 2012. Nanoparticles and their influence on radionuclide mobility in deep geological formations. Applied Geochemistry 27, 390-403.

Simpkins, L., 2011. Influence of natural organic matter on plutonium sorption to gibbsite.

Sirivithayapakorn, S., Keller, A., 2003. Transport of colloids in saturated porous media: A pore-scale observation of the size exclusion effect and colloid acceleration. Water Resources Research 39, n/a-n/a.

SKB, 2010. Design and production of the KBS-3 repository. SKB internal report TR-10-12.

Stul, M.S., Van Leemput, L., 1982. Particle-size distribution, cation exchange capacity and charge density of deferrated montmorillonites. Clay Minerals 17, 209-215.

Ticknor, K.V., Vilks, P., Vandergraaf, T.T., 1996. The effect of fulvic acid on the sorption of actinides and fission products on granite and selected minerals. Applied Geochemistry 11, $555-565$.

Tournassat, C., Neaman, A., Villiéras, F., Bosbach, D., Charlet, L., 2003. Nanomorphology of montmorillonite particles: Estimation of the clay edge sorption site density by low-pressure gas adsorption and AFM observations. Am. Miner. 88, 1989-1995.

Turner, D.R., Pabalan, R.T., Bertetti, F.P., 1998. Neptunium(V) sorption on montmorillonite; an experimental and surface complexation modeling study. Clay Clay Min. 46, 256-269.

Vahlund, F., Hermansson, H., 2006. A direct numerical approach to solving the transport equations for radionuclide transport in fractured rock. SKB internal report R-04-50.

White, G.N., Zelazny, L.W., 1988. Analysis and implications of the edge structure of dioctahedral phyllosilicates. Clay Clay Min. 36, 141-146.

Wolf, M., Buckau, G., Geyer, S., 2004. Isolation and characterisation of new batches of GoHy-573 humic and fulvic acids., in: ed., G.B. (Ed.), Humic substances in performance assessment of nuclear waste disposal: Actinide and iodine migration in the far-field. Wissenschaftliche Berichte FZKA 6969, Forschungszentrum Karlsruhe, pp. 111-124. 
756 Wu, T., Amayri, S., Drebert, J., Loon, L.R.V., Reich, T., 2009. Neptunium(V) Sorption and 757 Diffusion in Opalinus Clay. Environmental Science \& Technology 43, 6567-6571.

758 Yu, S.M., Chen, C.L., Chang, P.P., Wang, T.T., Lu, S.S., Wang, X.K., 2008. Adsorption of $759 \mathrm{Th}(\mathrm{IV})$ onto Al-pillared rectorite: Effect of $\mathrm{pH}$, ionic strength, temperature, soil humic acid 760 and fulvic acid. Applied Clay Science 38, 219-226.

761 Zhang, W., Tang, X., Weisbrod, N., Guan, Z., 2012. A review of colloid transport in fractured 762 rocks. J. Mt. Sci. 9, 770-787.

763 Zhao, P., Zavarin, M., Kersting, A., Carroll, S., 2011. Sorption and Precipitation of Plutonium 764 in the Presence of Goethite at Elevated Temperatures. Lawrence Livermore National 765 Laboratory (LLNL), Livermore, CA.

766 Östhols, E., Bruno, J., Grenthe, I., 1994. On the influence of carbonate on mineral dissolution: 767 III. The solubility of microcrystalline ThO2 in CO2-H2O media. Geochim. Cosmochim. Acta $76858,613-623$. 